$$
\text { 第 }
$$

注垂硝連腦ル連腦實驗驗

射體酸續下ミ續下成材

, 前 $ᄌ$ 注垂子注垂績料言目

影葉卜射體了射體

響食り’前ル人前ビ

笽七影葉ナ影葉實

水二響食卜激会驗

エン盤り堵方次

皮水门水法

スビ エ厶 I

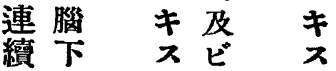

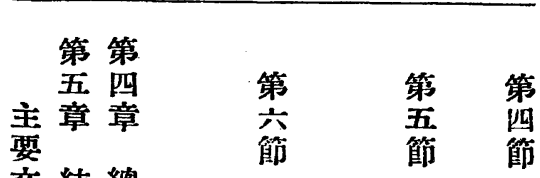

交 結 總

献括射體抱注垂硫連胋 及, 前水射體酸續下

論ビ影葉ク, 前 マ注垂

考響食口影葉攵射體

按盐ラ響食ネ, 前

水1 塯戝影葉

エル水ウ響食

キ及只盟

スビキ及水

連腦水王

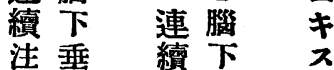

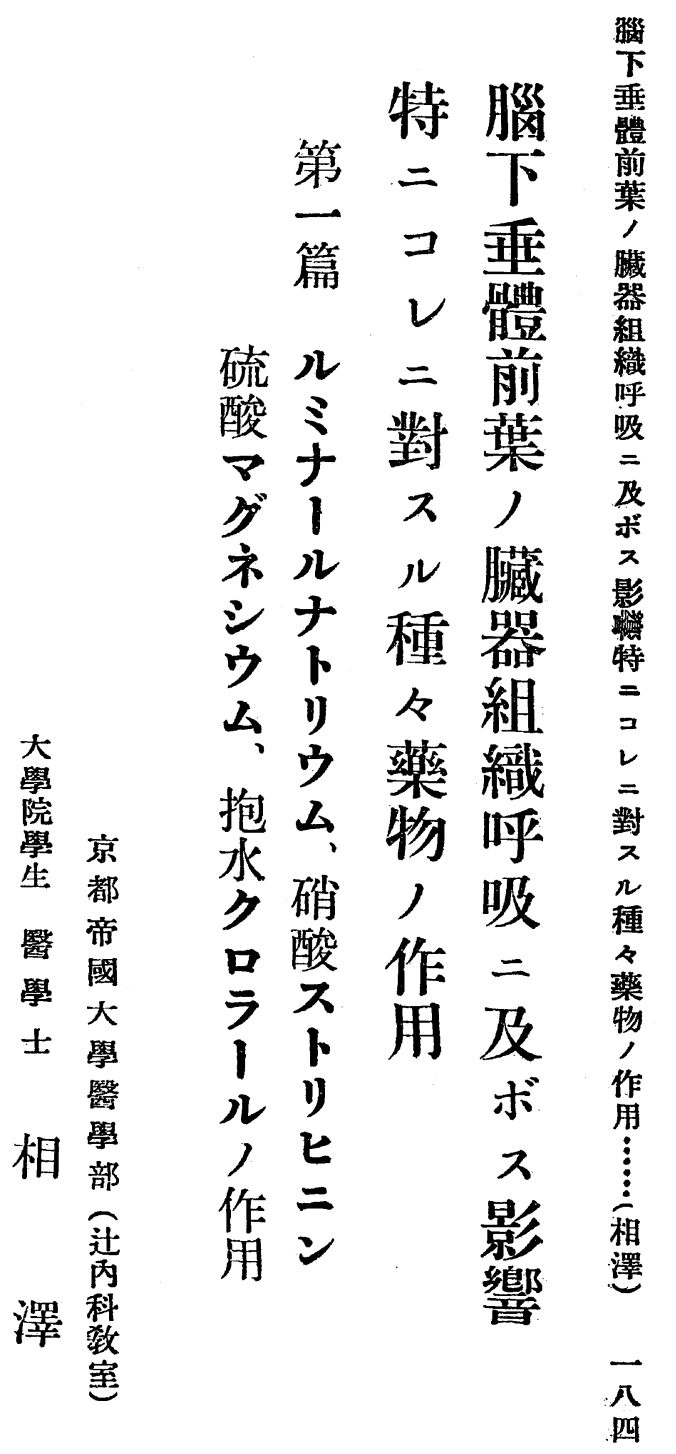

$\Rightarrow$

雄 


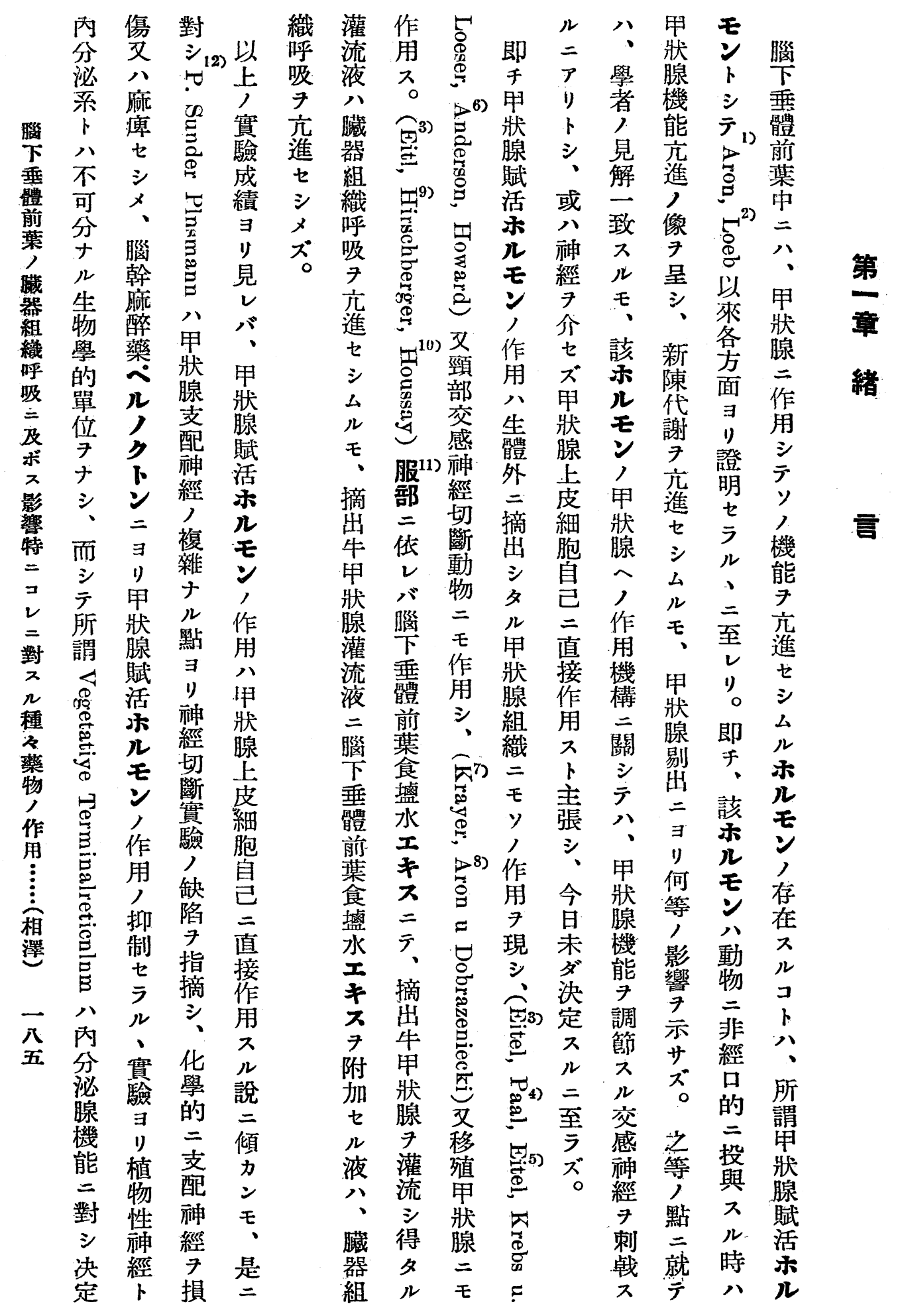




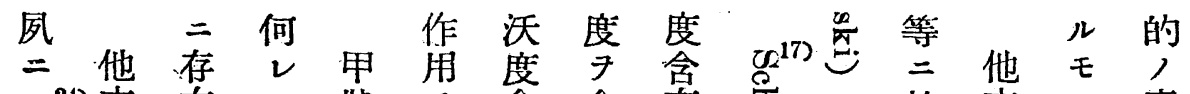

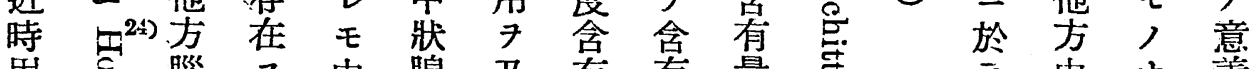

虫䐉

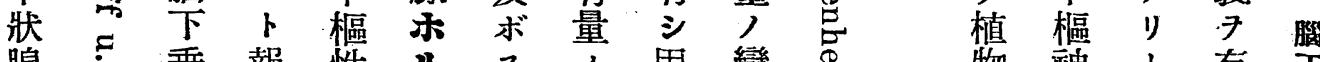

腺 垂 報性 几

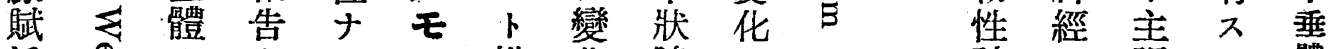

活导

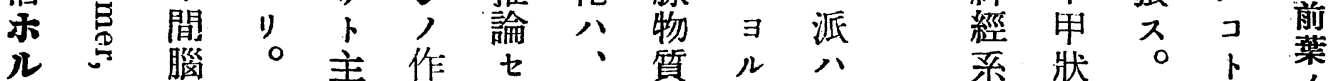

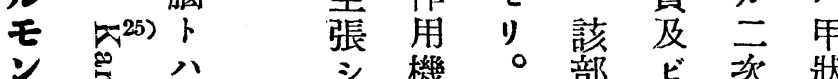

作 突 所

用 $\div$ 間

對 8 腦

ス $\mathbb{\mathscr { D }}$ T

儿 荧 垂

閶 $\bar{\sigma}^{26)}$ 鳢

意总点

義 元尔

特 部

等 學

間 報的

腦 報 告

醉紊機

藥 $\exists$ 能

$=$ 少 的

對 $\underset{\bar{x}}{\bar{x}}=$

ス 明密

態 为接

度ナ㜪

亚

コ 樆

ᄂ M

カ 關

バ係

导勇

紊

病皮

病

對齐

ス

三 機。部芷夲狀

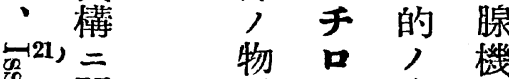

質 紗作能

三 的 $シ$ 用

テ 變シナ中

八 花 供 少榀

學學招

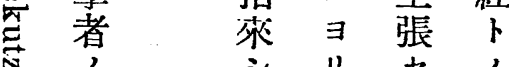

息箅間年關

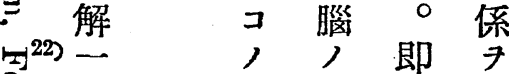

物 沃 致 特

～七 質度 彼

ザ 的 含 等 重

猃 變有公要

Ð $ト$ 化量 沃 視

$\Omega^{23)}$ 氏 中增菜

等 樞妿謝 告

他他、實體

$=$ 直甲驗於

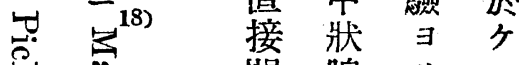

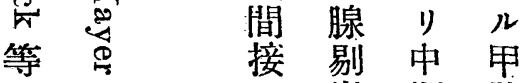

八E $E$ 出樞 狀

該 影二神腺

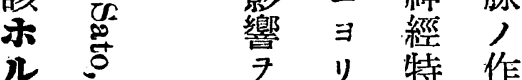

モ 受減

○家少少、八

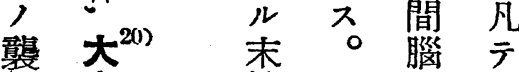

擊鹿梢コ八腦

點 了諸了多質

八諸現 間 量 內

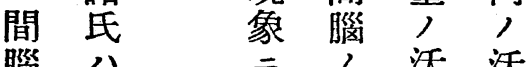

, 腺

異 $⺊$ 從器

常,

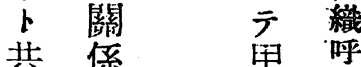

$=$ = 狀 吸

精 就 腺 文

神 キ 賦

障 テ活

碍 八影

伐凨㢣

伴凬五

コ學公=

个者 甲 $气$

八, 狀 對

周注 腺

知自止 $几$

人七皮種

事离細 細

賽 所 胞物

》。 直 作

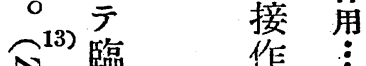

今㷊

穿

究点

病 六

粘 植

泣水性

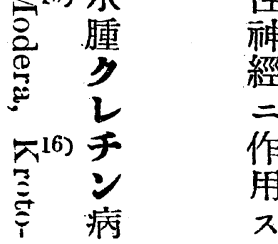




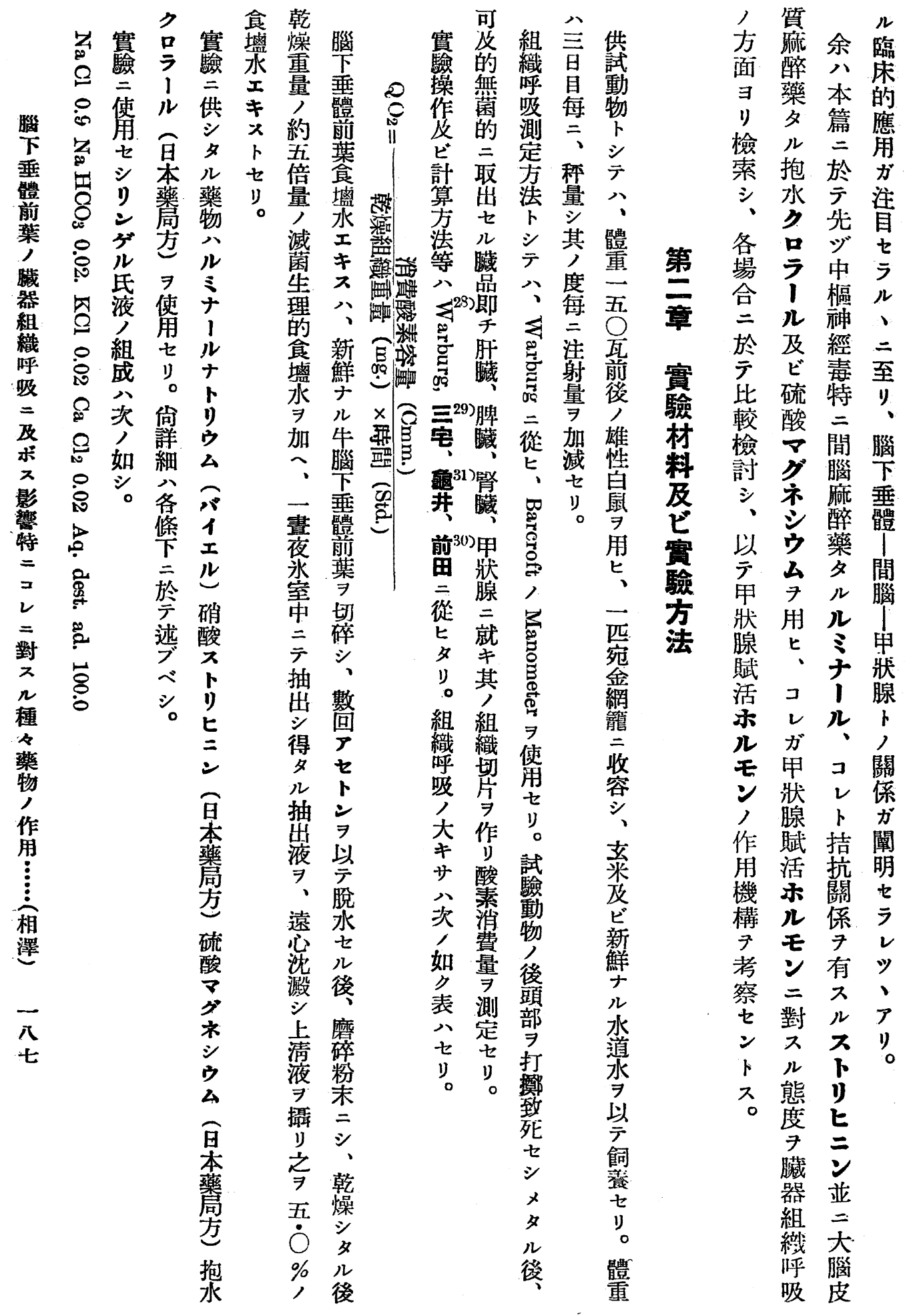


第一表 健 康 白 鼠 (對照)

\begin{tabular}{|c|c|c|c|c|c|}
\hline 月 日 & 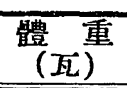 & $\begin{array}{c}\text { 䏦 藏 } \\
\mathrm{QHO}_{2}\end{array}$ & 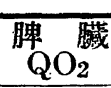 & 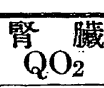 & $\begin{array}{c}\text { 甲爿腺 } \\
\mathrm{QO}_{2}\end{array}$ \\
\hline $6 / X$ & 147 & 10.81 & 8.97 & 21.19 & 9.08 \\
\hline $7 / 11$ & 152 & 9.83 & 9.96 & 20.95 & 7.59 \\
\hline $8 / 11$ & 124 & 9.73 & 8.85 & 19.48 & 9.70 \\
\hline $21 / 11$ & 161 & 9.80 & 11.36 & 22.11 & 10.74 \\
\hline $9 / X \mathrm{I}$ & 167 & 8.92 & 10.13 & 19.90 & 8.24 \\
\hline $18 / 11$ & 142 & 8.73 & 10.87 & 20.58 & 9.28 \\
\hline $19 / 11$ & 150 & 8.68 & 11.07 & 18.60 & 8.24 \\
\hline $24 / 11$ & 139 & 8.57 & 11.95 & 23.86 & 8.19 \\
\hline $25 / 11$ & 143 & 9.39 & 11.64 & 22.36 & 10.75 \\
\hline 2/XI & 148 & 10.26 & 12.51 & 22.31 & 8.27 \\
\hline $3 / 11$ & 142 & 9.29 & 10.76 & 22.91 & 9.03 \\
\hline $5 / 11$ & 130 & 9.98 & 9.20 & 23.02 & 8.91 \\
\hline $7 / 11$ & 164 & 9.57 & 11.99 & 22.51 & 8.82 \\
\hline 本 均 & 147 & 9.50 & 10.71 & 21.52 & 8.99 \\
\hline
\end{tabular}

第二表 腦下垂體前葉食螅水エキス注射白鼠

\begin{tabular}{|c|c|c|c|c|c|c|c|c|c|c|}
\hline \multirow[b]{2}{*}{ 月日 } & \multicolumn{2}{|c|}{ 體 重(瓦) } & \multirow{2}{*}{$\frac{\text { 肝 }}{\mathrm{QO}_{2}}$} & \multirow{2}{*}{ 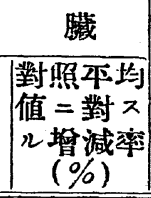 } & \multirow{2}{*}{$\begin{array}{r}\text { 脾 } \\
\mathrm{QO}_{2}\end{array}$} & \multirow{2}{*}{ 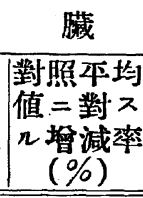 } & \multirow{2}{*}{$\begin{array}{c}\frac{\mathrm{p}^{2}}{\mathrm{QO}_{2}} \\
\end{array}$} & \multirow{2}{*}{ 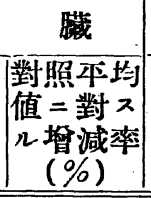 } & \multirow{2}{*}{$\frac{\text { 甲 }}{\mathrm{QO}_{2}}$} & \multirow{2}{*}{ 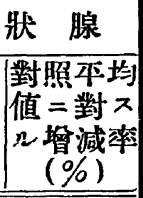 } \\
\hline & 洼射前 & 注射後 & & & & & & & & \\
\hline $7 / \mathrm{X}$ & 142 & 147 & 10.90 & +14.7 & 11.96 & $\mid+11.7$ & 22.32 & +3.7 & 10.01 & +11.4 \\
\hline $7 / 11$ & 131 & 130 & 9.86 & +3.8 & 10.20 & -4.8 & 22.36 & +3.9 & 10.81 & +19.2 \\
\hline $9 / .1$ & 145 & 143 & 9.81 & +3.3 & 11.50 & +7.4 & 24.05 & +11.3 & 9.13 & +1.6 \\
\hline $10 / / 1$ & 150 & 154 & 10.82 & +13.9 & 12.23 & +14.2 & 23.01 & +6.9 & 10.39 & +15.6 \\
\hline $0 / 11$ & 148 & 145 & 10.67 & +12.3 & 11.63 & +8.6 & 24.26 & +12.7 & 10.24 & +13.9 \\
\hline $13 /$ /" & 147 & 130 & 9.62 & +1.3 & 12.23 & +14.2 & 24.38 & +13.3 & 11.08 & +23.2 \\
\hline $30 / " 1$ & 148 & 151 & 10.36 & +9.1 & 12.58 & +17.5 & 24.29 & +12.9 & 10.04 & +11.7 \\
\hline $1 / X \llbracket$ & 150 & 168 & 10.02 & +5.5 & 12.94 & +20.8 & 22.85 & +6.4 & 9.88 & +9.9 \\
\hline $3 / 11$ & 139 & 138 & 12.68 & +33.5 & 13.00 & +21.4 & 24.13 & +12.1 & 11.30 & +26.7 \\
\hline $4 / 11$ & 148 & 150 & 11.39 & +19.9 & 13.76 & +28.5 & 26.29 & +22.2 & 11.61 & +29.1 \\
\hline 均 & 145 & 146 & 10.61 & +11.7 & 12.20 & +13.9 & 23.79 & +10.5 & 10.45 & +16.2 \\
\hline
\end{tabular}




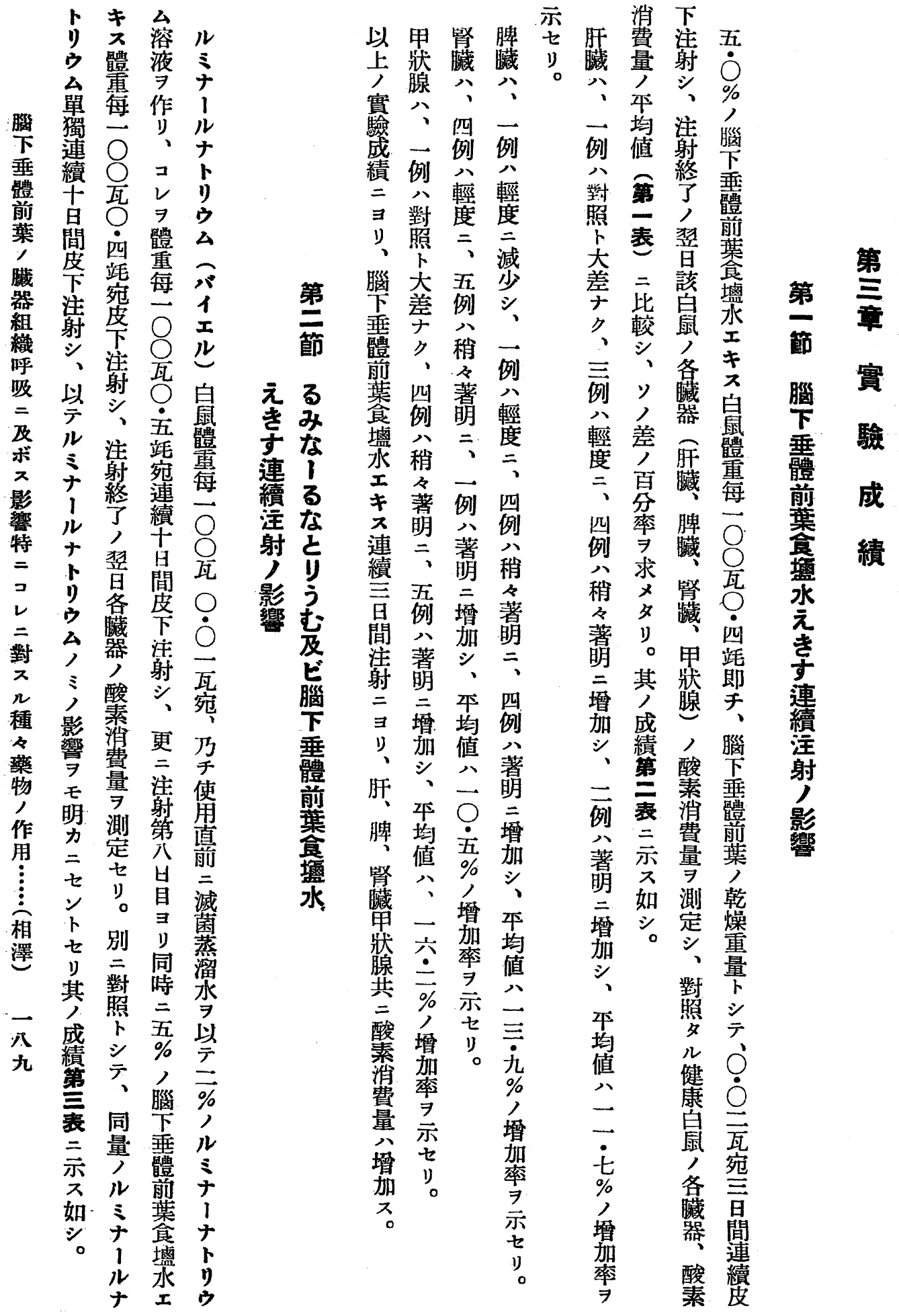


第 三 表

\begin{tabular}{|c|c|c|c|c|c|c|c|c|c|c|}
\hline \multirow[b]{2}{*}{ 月日 } & \multicolumn{2}{|c|}{ 體 重 (瓦) } & \multirow{2}{*}{$\frac{\text { 肝 }}{\mathrm{QO}_{2}}$} & \multirow{2}{*}{ 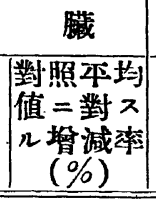 } & \multirow[t]{2}{*}{ 蚞 } & \multirow{2}{*}{ 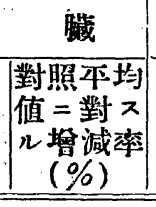 } & \multicolumn{2}{|c|}{ 腎臟 } & \multirow{2}{*}{\multicolumn{2}{|c|}{\begin{tabular}{c|c} 
甲 & 狀 腺 \\
$\mathrm{QO}_{2}$ & $\begin{array}{l}\text { 對照平均 } \\
\text { 值=對 } \\
\text { 增減率 } \\
(\%)\end{array}$ \\
\end{tabular}}} \\
\hline & 注射前 & 注射啳 & & & & & $\mathrm{QO}_{2}$ & 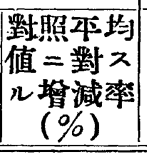 & & \\
\hline \multicolumn{11}{|c|}{ - } \\
\hline $7 / X$ & 145 & 143 & 8.58 & -9.7 & 10.94 & +2.1 & 21.18 & -1.6 & 9.18 & +2.1 \\
\hline $8 / 11$ & 145 & 145 & 6.88 & -27.6 & 10,68 & -0.3 & 20.59 & -4.3 & 8.20 & -8.8 \\
\hline $9 / 1 /$ & 145 & 156 & 10.00 & +5.3 & 10.34 & -3.5 & 21.49 & -0.1 & 10.93 & +21.6 \\
\hline $10 / \|$ & 143 & 154 & 10.49 & +14.2 & 10.21 & -4.7 & 22.87 & +6.3 & 8.50 & -5.5 \\
\hline $12 / 11$ & 147 & 151 & 11.07 & +16.5 & 11.84 & +10.6 & 23.81 & +1.3 & 9.16 & +1.9 \\
\hline $13 / \|$ & 172 & 192 & 9.41 & -0.9 & 11.36 & +6.1 & 23.21 & +7.9 & 9.53 & +6.0 \\
\hline $14 / " 1$ & 158 & 158 & 10.49 & +14.2 & 10.00 & -6.6 & 22.92 & +6.5 & 8.45 & -6.0 \\
\hline $2 / X I$ & 132 & 143 & 9.27 & -2.4 & 9.68 & -9.6 & 20.23 & -6.0 & 8.35 & -7.1 \\
\hline $3 / 11$ & 149 & 150 & 9.15 & -3.7 & 10.51 & -1.9 & 22.36 & +3.9 & 9.53 & +6.0 \\
\hline 平均 & 149 & 155 & 9.48 & -3.0 & 10.62 & -0.8 & 22.08 & +2.6 & 9.09 & +1.1 \\
\hline \multicolumn{11}{|c|}{ ルミナールナトリウム腦下垂體前葉食㸃水エキス注射白鼠 } \\
\hline $30 / X$ & 143 & 153 & 9.77 & +2.8 & 11.21 & +4.7 & 23.36 & +8.6 & 9.20 & +2.3 \\
\hline $2 / X I$ & 157 & 176 & 9.69 & +1.8 & 11.83 & +10.5 & 23.23 & +7.9 & 9.11 & +1.3 \\
\hline $2 / 11$ & 175 & 185 & 9.07 & -4.5 & 12.53 & +17.0 & 20.55 & -4.5 & 8.32 & -7.5 \\
\hline $4 / 11$ & 171 & 185 & 8.86 & -6.7 & 10.40 & -2.9 & 23.70 & +10.1 & 8.86 & -1.4 \\
\hline $5 / 11$ & 168 & 171 & 8.41 & -11.5 & 10.95 & +2.2 & 21.20 & +1.0 & 9.80 & +9.0 \\
\hline $5 / 11$ & 143 & 135 & 9.70 & +2.1 & 9.45 & -11.8 & 22.74 & +5.7 & 9.35 & +4.0 \\
\hline $6 / 11$ & 151 & 152 & 8.44 & -11.2 & 10.03 & -6.3 & 22.40 & +4.1 & 8.66 & -3.7 \\
\hline $6 / \mathrm{XI}$ & 142 & 146 & 10.02 & +5.5 & 10.08 & $-\quad 5.9$ & 22.80 & +5.9 & 9.67 & +7.6 \\
\hline 平均 & 156 & 163 & 9.25 & -2.6 & 10.81 & +0.9 & 22.50 & +4.6 & 9.12 & +1.4 \\
\hline \multicolumn{4}{|c|}{ 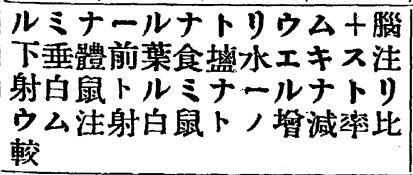 } & +0.4 & & +1.7 & & +2.0 & & +0.3 \\
\hline \multicolumn{4}{|c|}{ 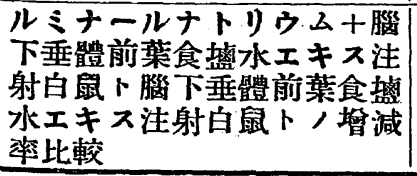 } & -14.3 & & -13.0 & & -5.9 & & -14.8 \\
\hline
\end{tabular}




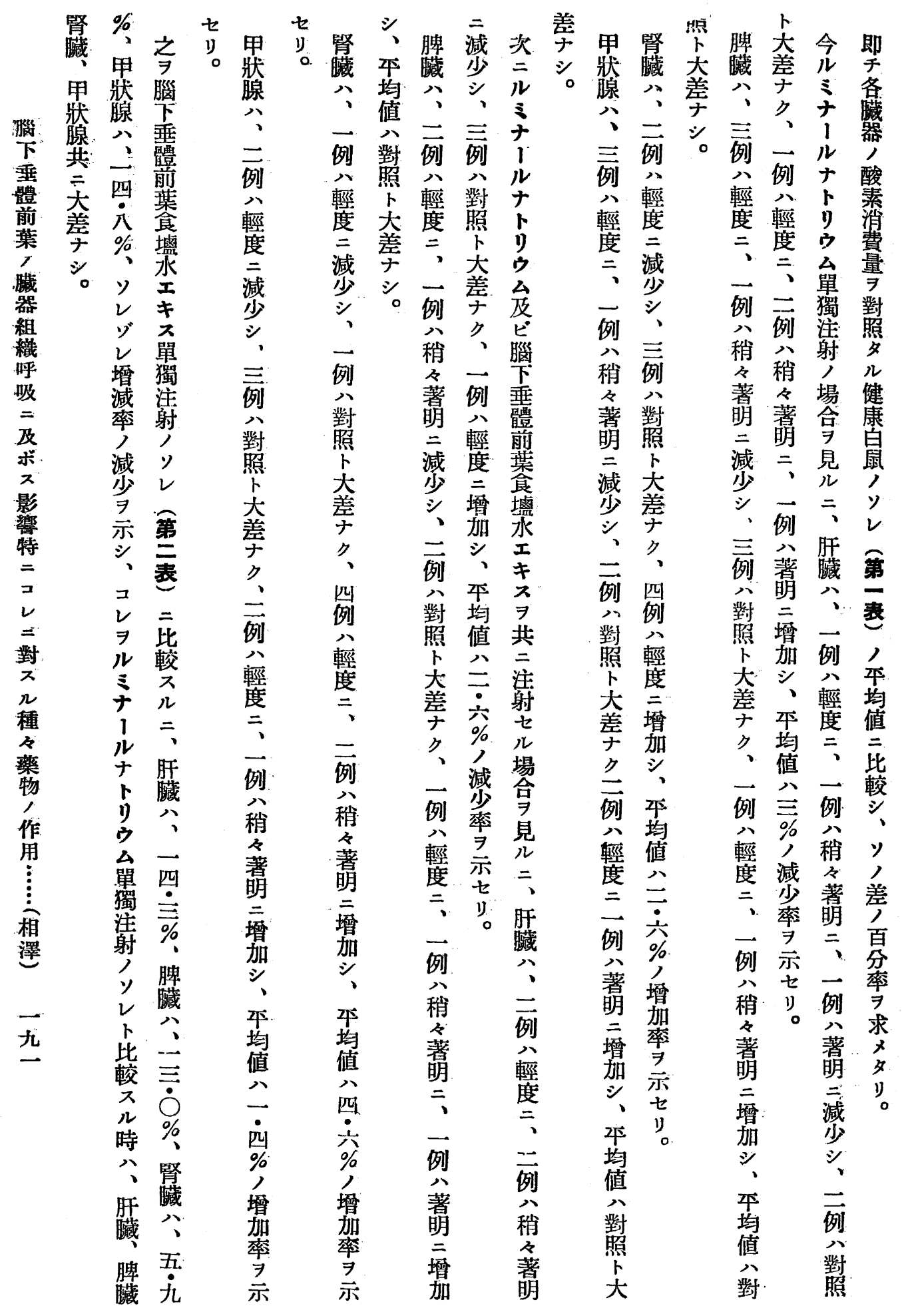




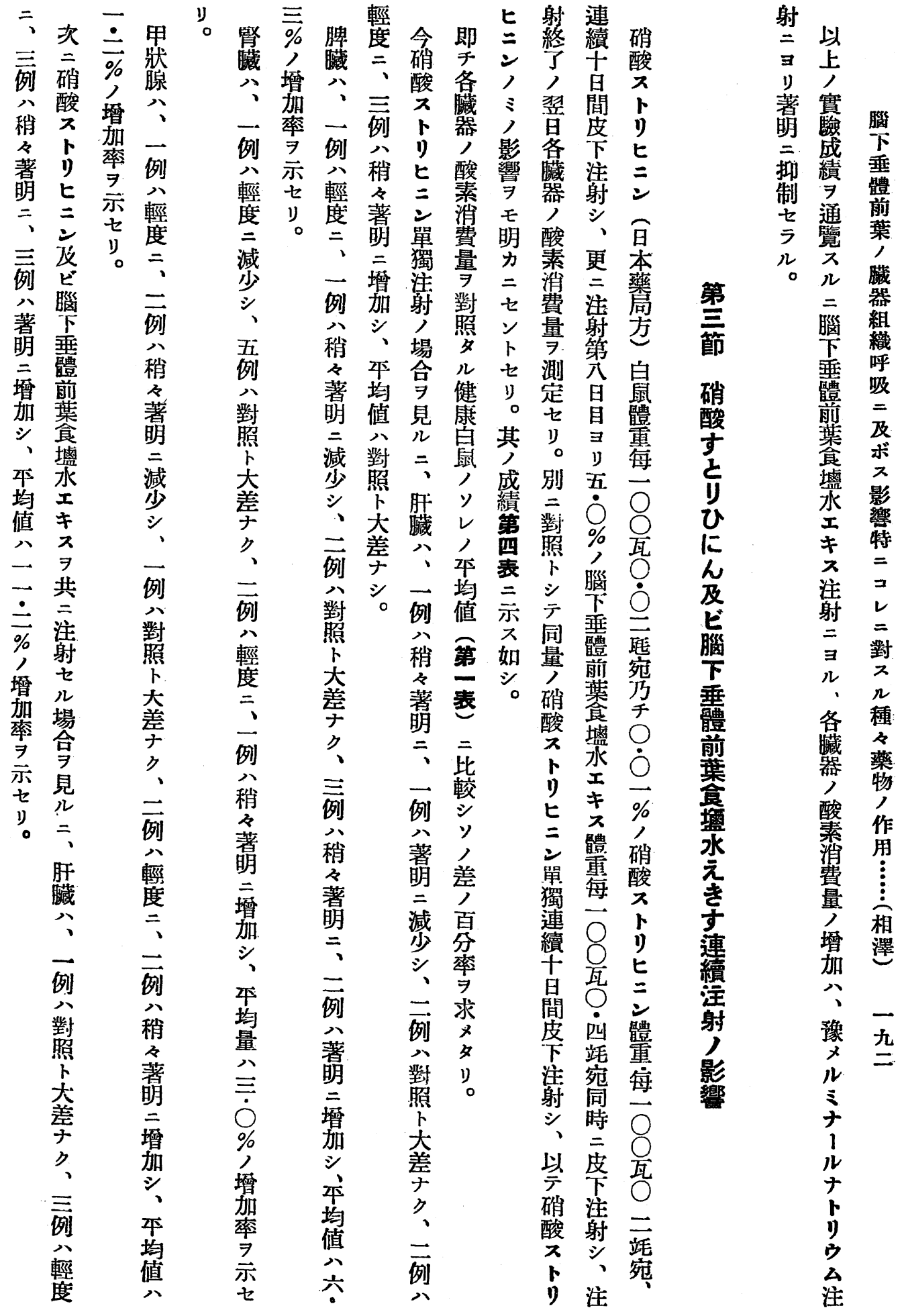




\begin{tabular}{|c|c|c|c|c|c|c|c|c|c|c|}
\hline \multirow[b]{2}{*}{ 月日 } & \multicolumn{2}{|c|}{ 體＼cjkstart重（瓦） } & \multirow{2}{*}{$\frac{\text { 肝 }}{\mathrm{QO}_{2}}$} & \multirow{2}{*}{\begin{tabular}{|c|}
\multicolumn{1}{c|}{ 臟 } \\
對照平均 \\
值=對 \\
$n$ 增減率 \\
$(\%)$
\end{tabular} \mid} & \multirow{2}{*}{$\frac{\text { 脾 }}{\mathrm{QO}_{2}}$} & \multirow{2}{*}{ 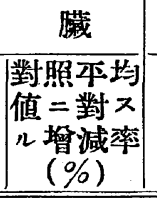 } & \multirow{2}{*}{\multicolumn{2}{|c|}{ 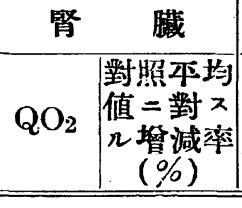 }} & \multirow{2}{*}{ 甲 } & \multirow{2}{*}{ 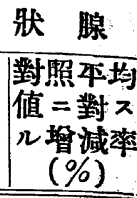 } \\
\hline & 注射前 & 注射後 & & & & & & & & \\
\hline \multicolumn{11}{|c|}{ 硝酸ストリヒニン注射白鼠 } \\
\hline $14 / X$ & 139 & 134 & 9.50 & $\pm \quad 0$ & 10.38 & -3.1 & 21.77 & +1.2 & 9.46 & $1+5.2$ \\
\hline $15 / / \prime$ & 130 & 127 & 10.33 & +8.7 & 10.58 & -1.2 & 21.64 & +0.6 & & \\
\hline $16 / "$ & 153 & 172 & 10.09 & +6.2 & 12.79 & +19.4 & 20.72 & -3.7 & 8.67 & -3.6 \\
\hline $19 / / 1$ & 127 & 135 & 10.59 & +11.5 & 12.34 & +15.2 & 22.09 & +2.6 & 9.87 & +9.8 \\
\hline $19 / " /$ & 157 & 165 & 7.64 & -19.6 & 11.73 & +9.5 & 22.07 & +2.6 & 10.44 & +16.1 \\
\hline $20 / \|$ & 147 & 165 & 9.87 & +3.9 & 11.89 & +10.9 & 23.14 & +7.5 & 8.94 & -0.6 \\
\hline $30 / X I$ & 165 & 185 & 9.32 & -1.9 & 12.21 & +14.0 & 24.97 & +11.4 & 8.09 & -10.0 \\
\hline $5 / \mathrm{XI}$ & 159 & 175 & 10.48 & +10.3 & 10.88 & +1.6 & 22.39 & +4.0 & 9.37 & +4.2 \\
\hline $16 / " /$ & 138 & 140 & 8.63 & -9.2 & 9.58 & -10.6 & 21.70 & $-\quad 0.9$ & 8.04 & -10.6 \\
\hline 本均 & 146 & 155 & 9.61 & +1.1 & 11.38 & +6.3 & 22.28 & +3.0 & 9.11 & +1.2 \\
\hline \multicolumn{11}{|c|}{ 硄酸ストリヒニン十腦下垂體前葉食㿿水エキス注射白鼠 } \\
\hline $25 / \mathrm{XI}$ & 154 & 168 & 10.46 & +10.1 & 12.76 & +19.1 & 23.40 & +8.7 & 10.71 & +19.6 \\
\hline $25 / 11$ & 134 & 142 & 10.04 & +5.7 & 11.64 & +8.7 & 23.49 & +9.2 & 10.18 & +13.2 \\
\hline $26 / 11$ & 137 & 136 & 10.98 & +15.6 & 12.44 & +16.2 & 23.70 & +10.1 & 9.58 & +6.6 \\
\hline $27 / \|$ & 135 & 135 & 9.42 & -0.8 & 12.59 & +17.6 & 25.14 & +12.1 & 10.31 & +14.7 \\
\hline $28 / 1 "$ & 120 & 125 & 10.08 & +6.1 & 10.22 & -4.6 & 23.82 & +10.7 & 10.53 & +17.1 \\
\hline $30 / 11$ & 150 & 148 & 10.98 & +15.6 & 11.57 & +8.0 & 23.51 & +9.2 & 10.32 & +14.8 \\
\hline $30 / / 1$ & 148 & 153 & 10.53 & +10.8 & 11.70 & +9.7 & 22.76 & +5.8 & 10.72 & +19.4 \\
\hline $1 /$ XI & 142 & 151 & 10.56 & +11.2 & 12.85 & +20.0 & 23.80 & +10.6 & 9.85 & +9.6 \\
\hline $5 / \|$ & 140 & 143 & 12.28 & +29.3 & 13.09 & +22.2 & 26.31 & +22.3 & 12.81 & +42.6 \\
\hline $7 / 11$ & 145 & 162 & 10.23 & +7.8 & 13.00 & +21.4 & 23.09 & +7.8 & 9.05 & -0.7 \\
\hline 平均 & 141 & 146 & 10.56 & +11.2 & 12.19 & +13.8 & 23.90 & +11.5 & 10.41 & +15.8 \\
\hline \multicolumn{4}{|c|}{ 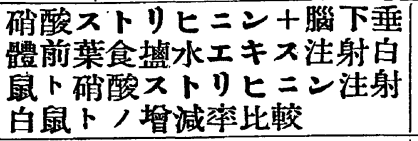 } & +10.1 & & +7.5 & & +8.5 & & +14.6 \\
\hline \multicolumn{4}{|c|}{ 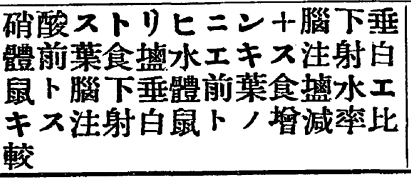 } & -0.5 & & -0.1 & & +1.0 & & -0.4 \\
\hline
\end{tabular}




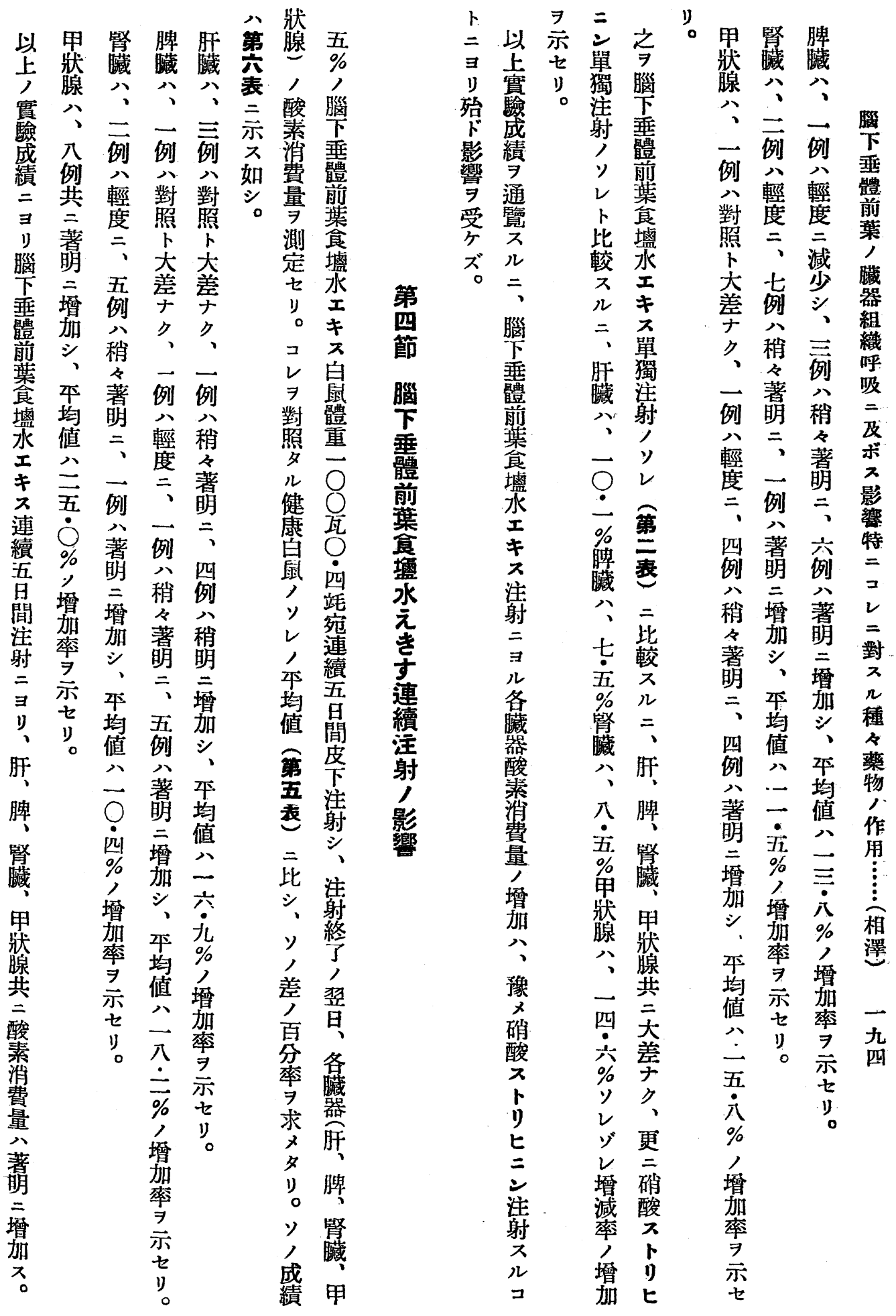




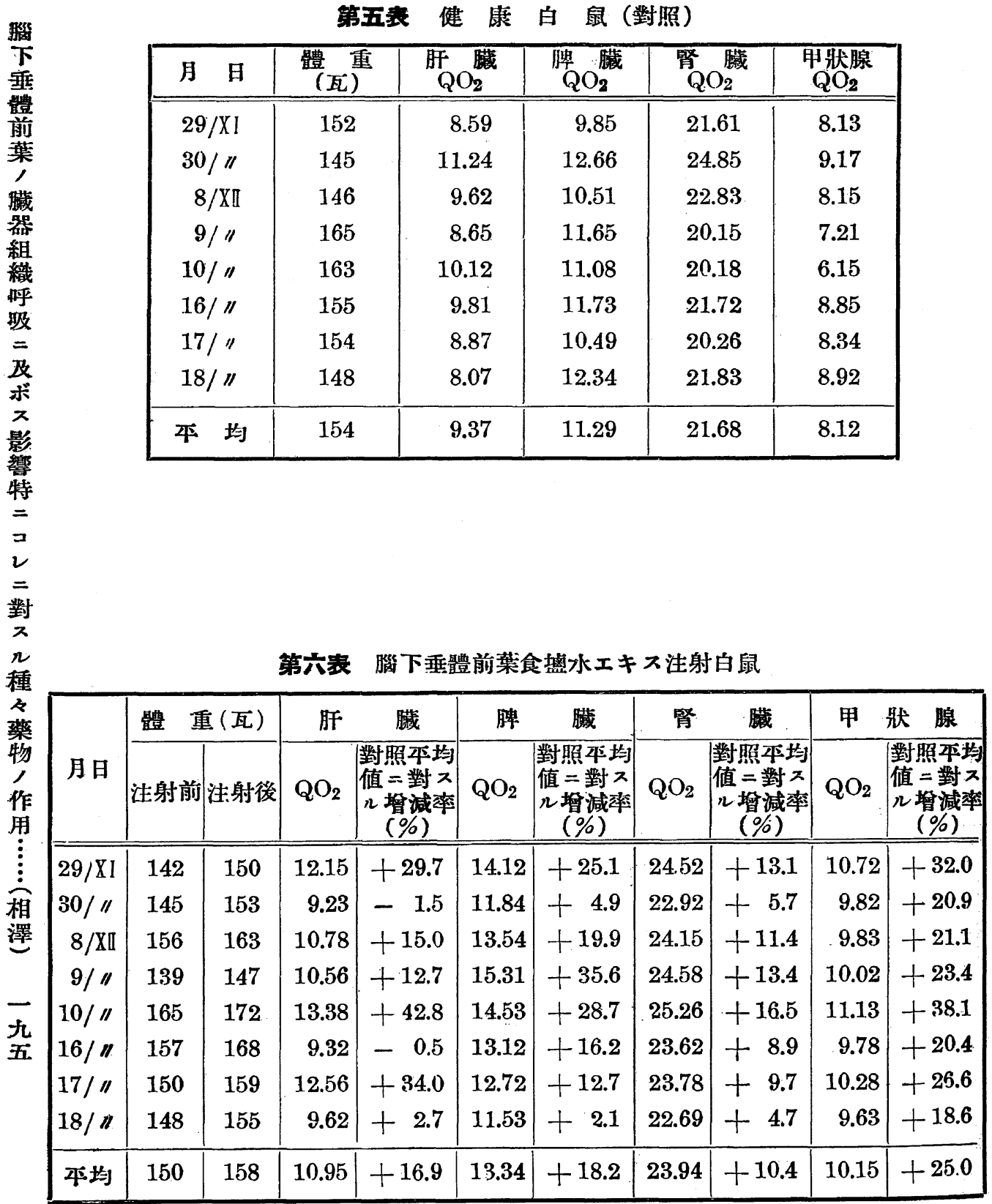




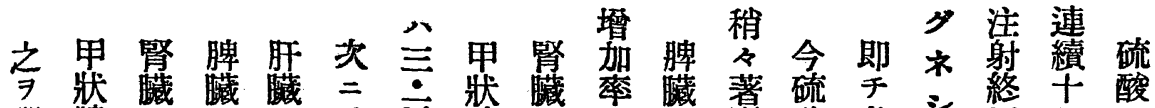

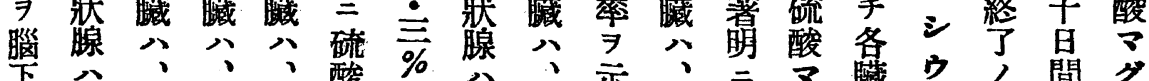
垂、四一二酸

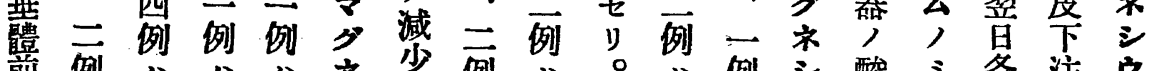

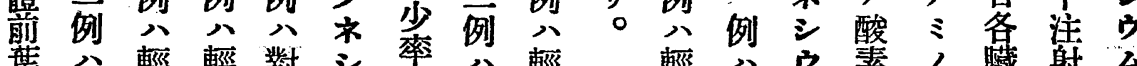
葉 輕輕對

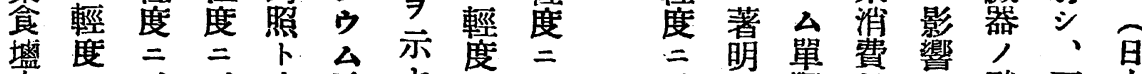
永 $=$ 、

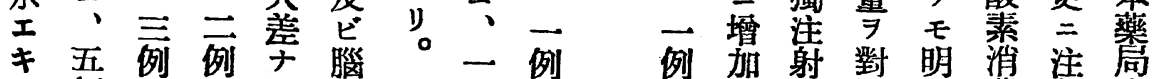

不例分盟

單分稍稍、垂

獨著名冬一體

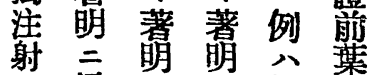
, 增 二三輕 食 ソ加增、琵食 $\checkmark$ 、加四三水

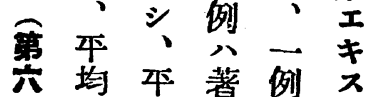

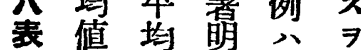
八值三稍 共 比九加著注 較 $三$ 六 明射 ス $\%$ \% 二堌增均四場

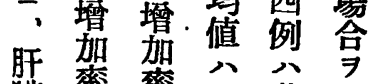

肝 架 䔞 八示示公奛

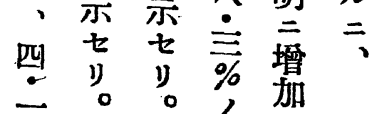

㹂

早
例 例

著

稍 奛

著減

奛 少

$=$ シ

例例

著輕

奛度

減

少 㤩

一鉴

例

分萻

對

照 增

点

琴

少䏒

例 對

八 照

稍

壃差

明 シ

增

妿

率

示

增

加

平

例加射對明消乼扁

稍、場多二量第方籍租

々本合 $九 户$ 六白呼

著均寻健ン測白鼠硫吸

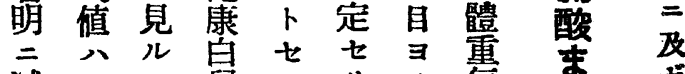
減 二 =鼠 。 少 言旰り 其 別時 $\vec{\bigcirc}$ 小影

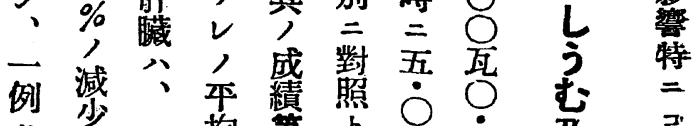

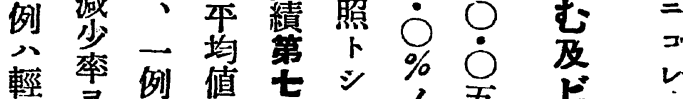
度 $\rightrightarrows$ 例值 七表

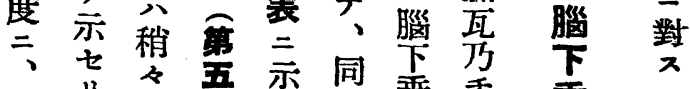

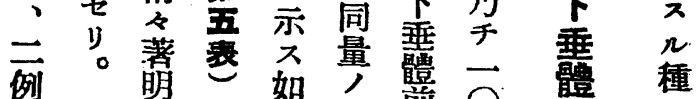
分

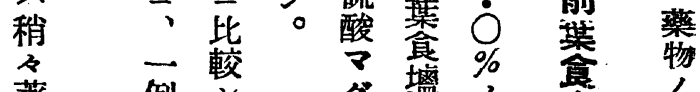

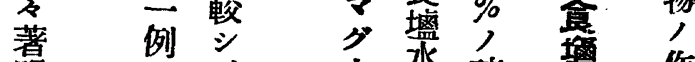
明八、齐水硫俑作 二著り 济酸水用 、著当

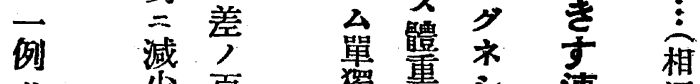
著省夏盪重方連澤

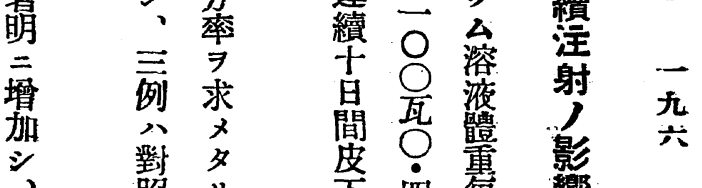
悬 舸

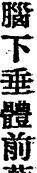

人

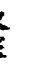

等

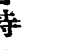




\begin{tabular}{|c|c|c|c|c|c|c|c|c|c|c|}
\hline \multirow[b]{2}{*}{ 月日 } & \multicolumn{2}{|c|}{ 體 重(瓦) } & \multicolumn{2}{|l|}{ 肝 } & 脾 & 臟 & 腎 & 贜 & \multicolumn{2}{|c|}{ 甲 狀 腺 } \\
\hline & 注射前 & 注射後 & $\mathrm{QO}_{2}$ & $\mid \begin{array}{c}\text { 對照平均 } \\
\text { 增減率 } \\
(\%)\end{array}$ & $\mathrm{QO}_{2}$ & 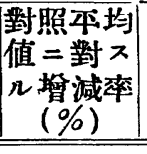 & $\mathrm{QO}_{2}$ & 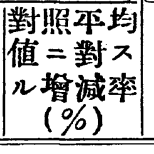 & $\mathrm{QO}_{2}$ & 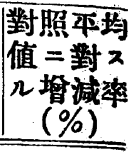 \\
\hline \multicolumn{11}{|c|}{ 硫酸ムダネシウム注射白鼠 } \\
\hline $1 / \mathrm{XI}$ & 148 & 155 & 9.35 & -0.2 & 13.02 & +15.3 & 20.91 & -3.6 & 7.58 & -6.4 \\
\hline $2 / 11$ & 156 & 163 & 7.15 & -23.7 & 9.65 & $-14,5$ & 17.53 & -19.1 & 6.05 & -25.5 \\
\hline $3 / \prime \prime$ & 165 & 175 & 9.13 & -2.6 & 10.81 & -4.3 & 23.62 & +8.9 & 7.10 & -12.6 \\
\hline $11 / \|$ & 158 & 169 & 10.56 & +12.7 & 12.23 & +8.3 & 22.71 & +4.8 & 8.81 & +8.4 \\
\hline $12 / "$ & 142 & 150 & 9.20 & -1.6 & 12.76 & +13.0 & 23.72 & +9.5 & 8.32 & +2.5 \\
\hline $20 / 11$ & 145 & 158 & 10.82 & +15.5 & 11.73 & +3.9 & 20.12 & -7.2 & 9.26 & +14.0 \\
\hline $21 / "$ & 143 & 149 & 8.62 & -8.0 & 10.53 & -6.7 & 23.52 & +8.5 & 7.85 & -3.3 \\
\hline 平均 & 151 & 158 & 9.26 & -1.2 & 11.53 & +2.1 & 21.73 & -0.9 & 7.85 & -3.3 \\
\hline \multicolumn{11}{|c|}{ 硫酸マダネシウム+腦下垂娟前葉食盐水エキス注射白鼠 } \\
\hline $1 / X \llbracket$ & 165 & 178 & 10.54 & +12.5 & 13.62 & +20.6 & 23.07 & +6.4 & 9.65 & +18.8 \\
\hline $2 / 11$ & 143 & 150 & 10.81 & +16.0 & 12.52 & +10.9 & 24.38 & +12.5 & 9.92 & +22.4 \\
\hline $3 / 11$ & 148 & 157 & 10.85 & +15.8 & 13.55 & +20.0 & 24.65 & +13.2 & 10.26 & +26.4 \\
\hline $11 / \|$ & 152 & 165 & 9.51 & +1.5 & 12.61 & +11.7 & 23.51 & +8.4 & 8.59 & +5.8 \\
\hline $13 / "$ & 155 & 164 & 11.53 & +23.1 & 13.78 & +22.1 & 23.41 & +7.5 & 10.28 & +26.6 \\
\hline $20 / 11$ & 149 & 158 & 9.71 & +3.6 & 11.80 & +4.5 & 22.65 & +4.5 & 8.37 & +3.1 \\
\hline $21 / \|$ & 165 & 172 & 10.99 & +17.3 & 15.32 & +35.7 & 23.09 & +6.5 & 10.68 & +31.5 \\
\hline 本均 & 154 & 163 & 10.57 & +12.8 & 13.36 & +18.3 & 23.54 & +8.6 & 9.68 & +19.3 \\
\hline \multicolumn{4}{|c|}{ 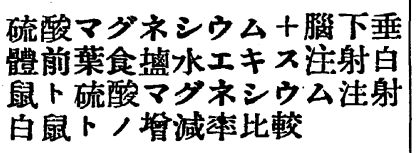 } & +14.0 & & +16.2 & & +9.5 & & +22.6 \\
\hline \multicolumn{4}{|c|}{ 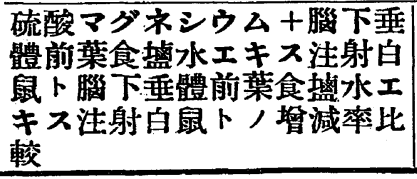 } & -4.1 & & +0.1 & & -1.8 & & -5.7 \\
\hline
\end{tabular}




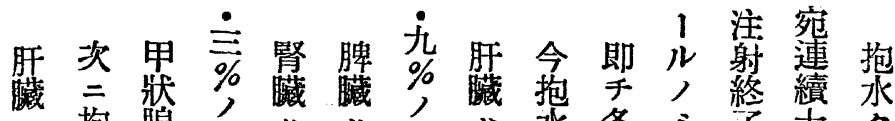

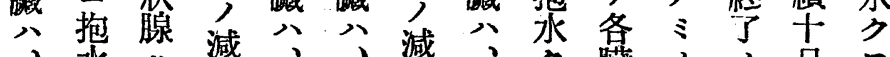

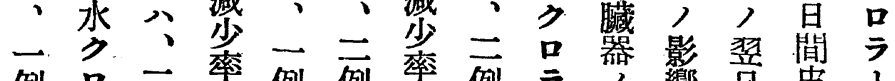

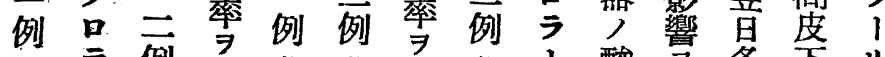

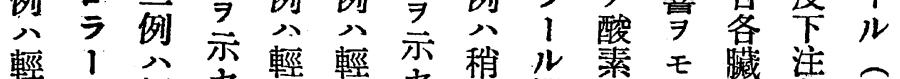

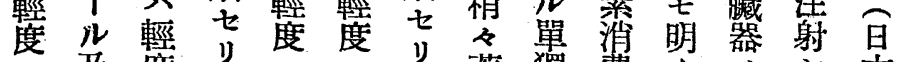

三及度

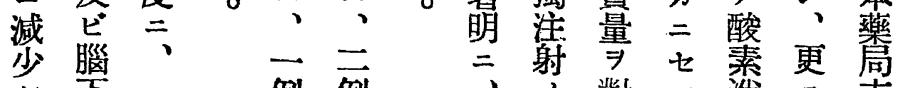

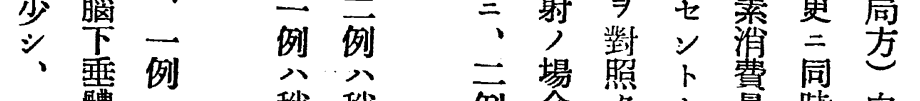

例䌡公㮐稍例合名七量時泉

例怔葉稍著著 著見健 。湘注體

輕食著 坦二奛儿康ソ定射重

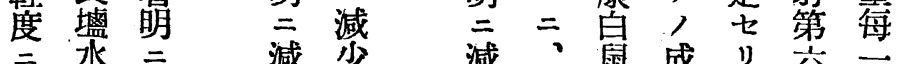

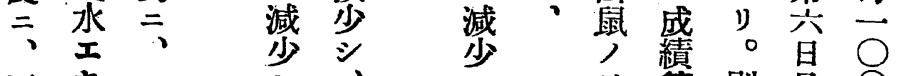

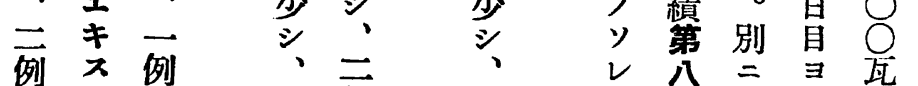

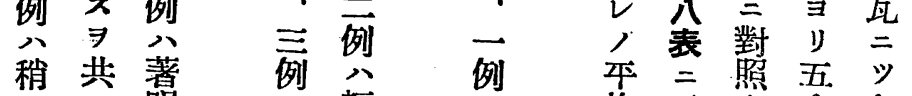

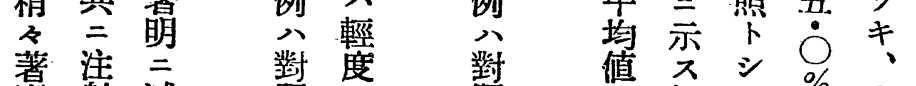

奛射減照二

$=セ$ 少

洌合三 揱 例

$\stackrel{r}{\mathrm{r}}$

著見分分萻

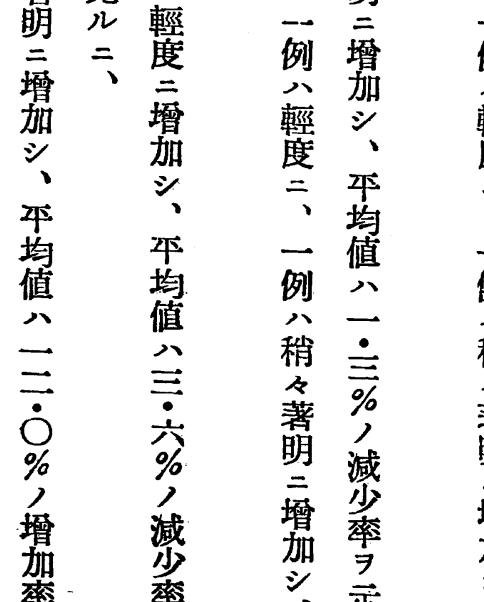

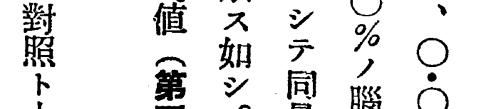

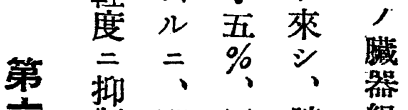

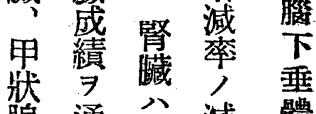

腺通 公減 體

八覽九少前

篩 制 㛴 甲脾 組

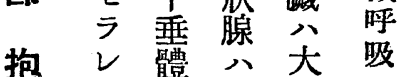

水脾䈎三盖示

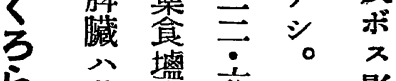

与藷盐六

る變 エ

及認爻硫=

ビメ注 ゾ酸コ

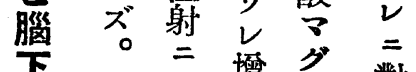

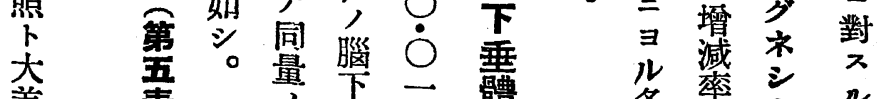

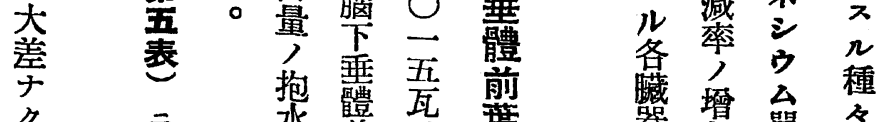

率 弯交

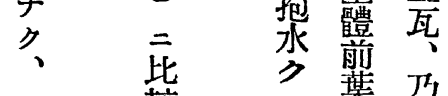

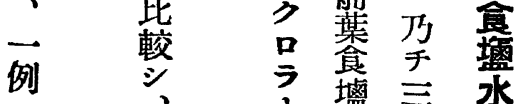

輕、搵

輕紧哭,

水

度 差 單蠋吉抱

充

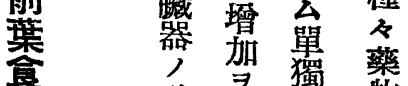

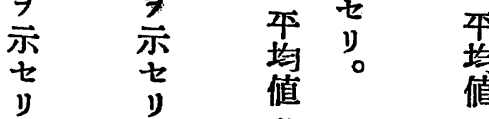

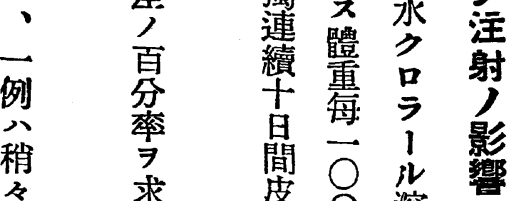

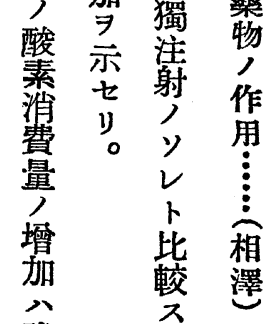

著 求 等 $\bigcirc$ 溶

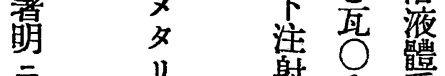

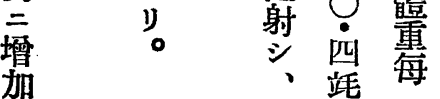

架

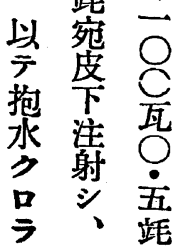

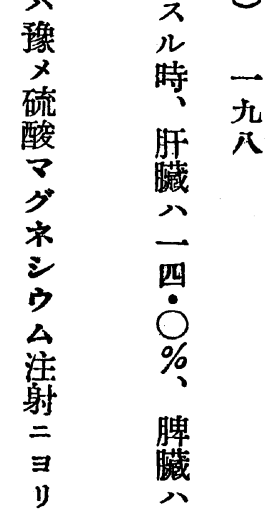


第八表

\begin{tabular}{|c|c|c|c|c|c|c|c|c|c|c|}
\hline \multirow[b]{2}{*}{ 月日 } & \multicolumn{2}{|c|}{ 體 重(瓦) } & \multirow{2}{*}{$\frac{\text { 肝 }}{\mathrm{QO}_{2}}$} & \multirow{2}{*}{ 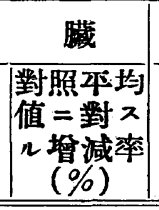 } & \multirow{2}{*}{$\begin{array}{r}\text { 脾 } \\
\mathrm{QO}_{2}\end{array}$} & \multirow{2}{*}{ 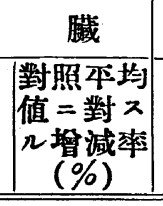 } & \multirow{2}{*}{$\begin{array}{c}\text { 腎 } \\
\mathrm{QO}_{2}\end{array}$} & \multirow{2}{*}{ 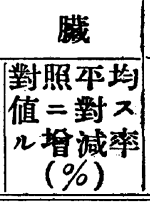 } & \multirow{2}{*}{$\frac{\text { 甲 }}{\mathrm{QO}_{2}}$} & \multirow{2}{*}{ 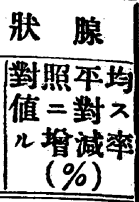 } \\
\hline & 注射前 & 注射後 & & & & & & & & \\
\hline \multicolumn{11}{|c|}{ 抱水クロラール注射白鼠 } \\
\hline $4 / \mathrm{XI}$ & 160 & 172 & 9.82 & +4.8 & 13.05 & +15.6 & 23.72 & +9.4 & 8.63 & +6.3 \\
\hline $6 / 11$ & 153 & 165 & 7.76 & -20.8 & 11.81 & +4.6 & 20.31 & -6.3 & 6.23 & -23.3 \\
\hline $7 / 11$ & 154 & 162 & 9.41 & +0.4 & 11.71 & +3.7 & 19.36 & -10.7 & 8.53 & +5.0 \\
\hline $14 / 1$ & 148 & 153 & 8.27 & -11.7 & 10.93 & -3.3 & 21.62 & -0.3 & 7.05 & -13.2 \\
\hline $15 / 11$ & 156 & 167 & 10.46 & +11.6 & 10.57 & -6.4 & 21.72 & +0.2 & 8.82 & +8.6 \\
\hline $22 / 11$ & 145 & 152 & 8.39 & -10.5 & 10.06 & -10.9 & 22.68 & +4.6 & 7.76 & -4.4 \\
\hline $23 / 11$ & 137 & 144 & 7.62 & -18.7 & 9.83 & -12.9 & 20.39 & -1.3 & 7.78 & -4.2 \\
\hline 平均 & 150 & 159 & 8.82 & -5.9 & 11.14 & -1.3 & 21.40 & -1.3 & 7.83 & -3.6 \\
\hline \multicolumn{11}{|c|}{ 抱水クロラール十腦下垂體前葉食譃水エキス注射白鼠 } \\
\hline $4 / X \llbracket$ & 142 & 150 & 10.44 & +11.4 & 14.12 & +25.1 & 24.51 & +13.0 & 9.36 & +15.3 \\
\hline $6 / 11$ & 158 & 167 & 8.87 & -5.3 & 11.36 & +0.6 & 22.81 & +5.2 & 8.61 & +6.0 \\
\hline $7 / 11$ & 147 & 156 & 11.58 & +23.6 & 14.07 & +24.6 & 23.76 & +9.6 & 10.83 & +23.4 \\
\hline $14 / "$ & 143 & 152 & 9.93 & +6.0 & 11.61 & +2.8 & 22.63 & -4.4 & 9.48 & +16.7 \\
\hline $15 / \prime \prime$ & 165 & 178 & 10.48 & +11.8 & 13.26 & +17.4 & 24.71 & +13.9 & 9.38 & +15.5 \\
\hline $22 / 11$ & 135 & 144 & 11.25 & +20.1 & 13.87 & +22.9 & 26.41 & +21.8 & 10.51 & +29.4 \\
\hline $23 / 11$ & 162 & 175 & 10.86 & +15.9 & 13.65 & +20.9 & 23.86 & +10.1 & 9.47 & +16.6 \\
\hline 平均 & 150 & 160 & $\mid 10.49$ & +12.0 & 13.13 & +16.3 & 24.01 & +10.8 & 9.66 & +17.7 \\
\hline \multicolumn{4}{|c|}{ 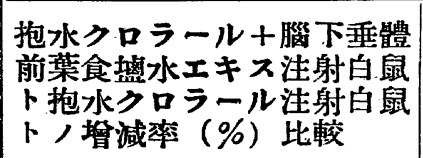 } & +17.9 & & +17.6 & & +12.1 & & +21.3 \\
\hline \multicolumn{4}{|c|}{ 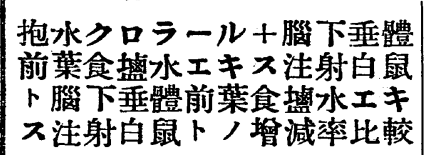 } & -4.9 & & -1.9 & & +0.4 & & -7.3 \\
\hline
\end{tabular}




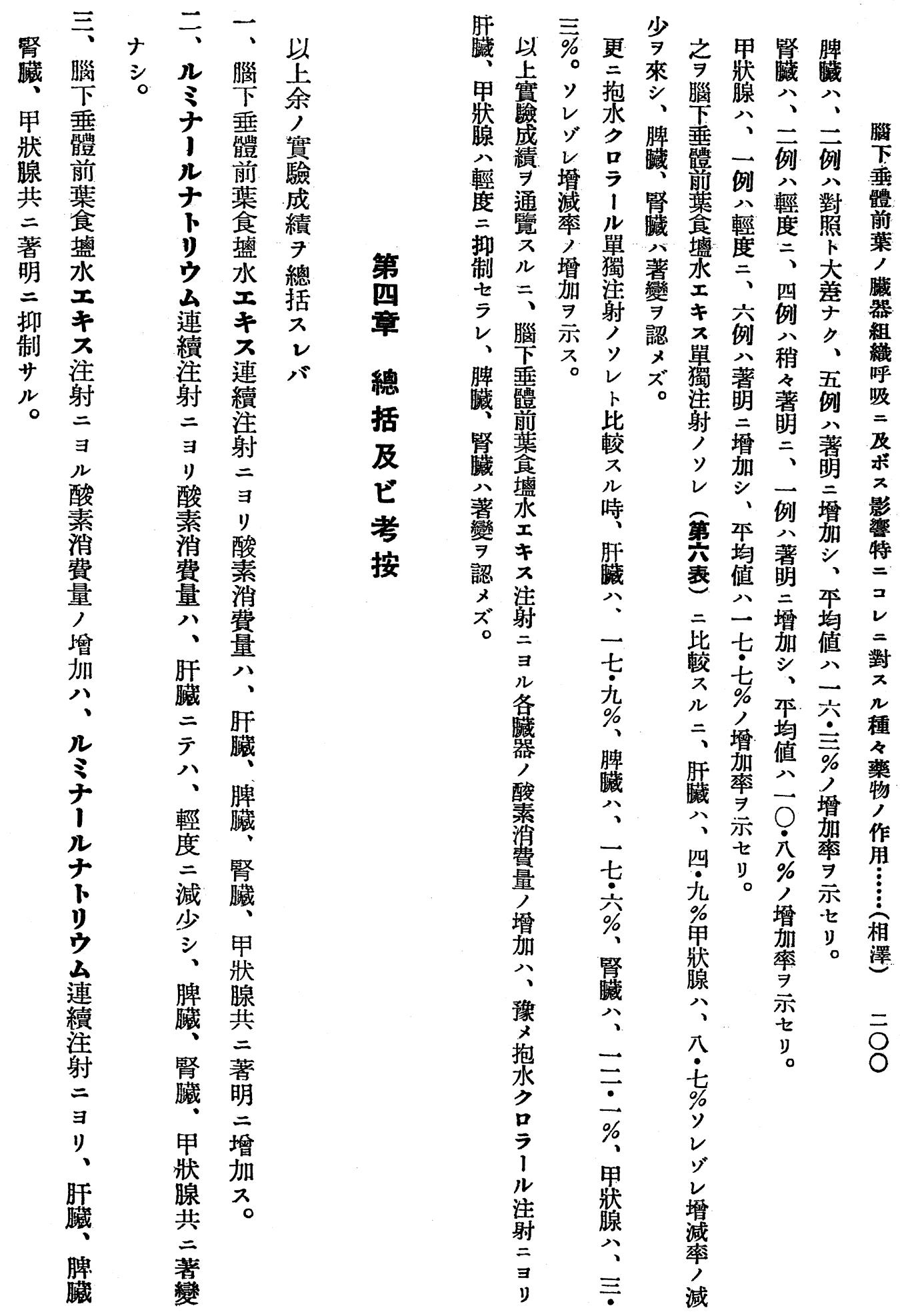




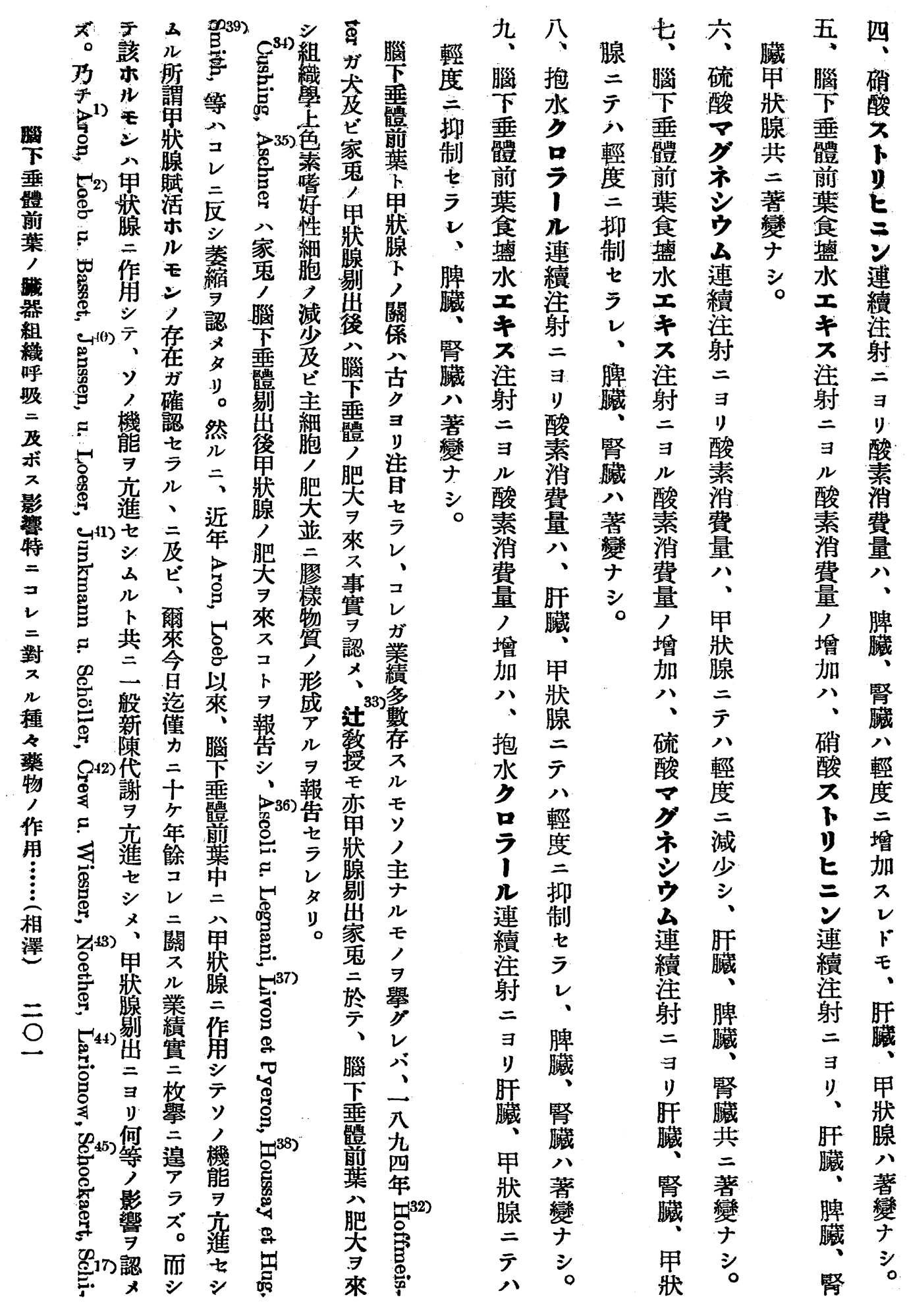




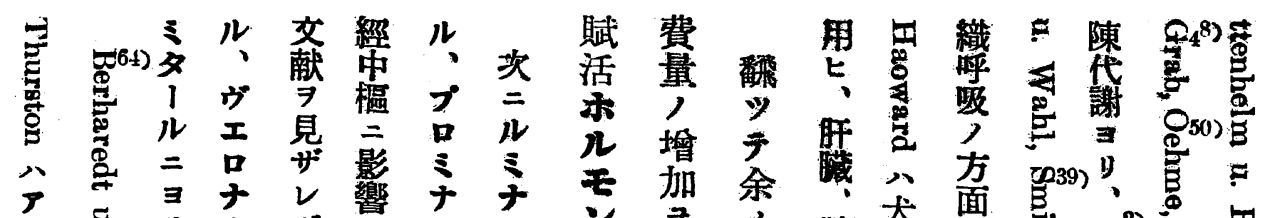

今

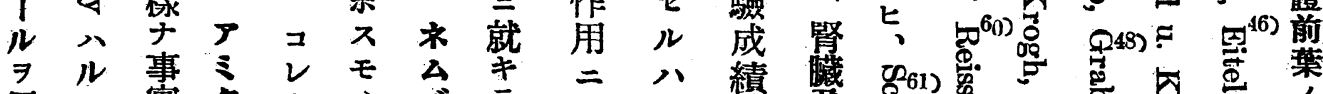

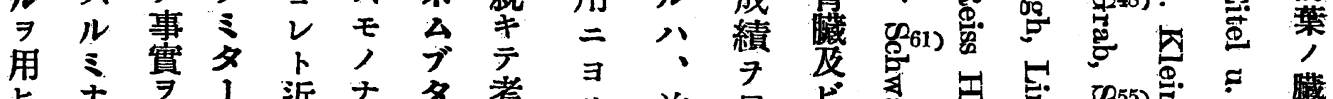

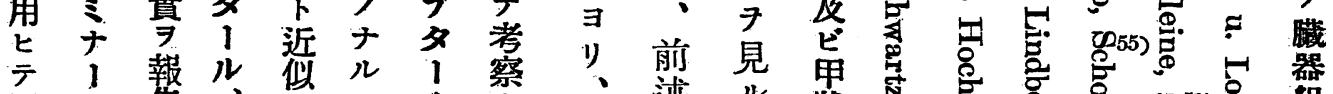

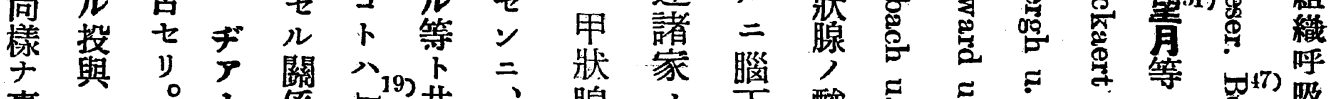
事與 。

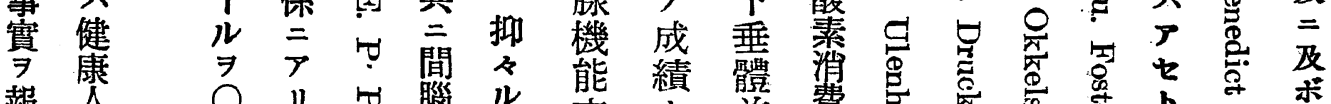

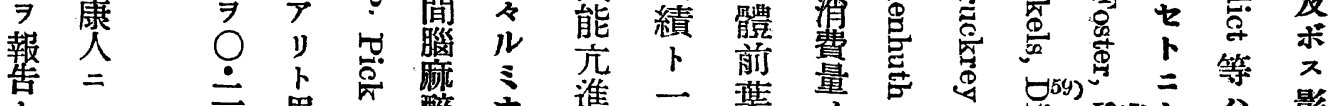

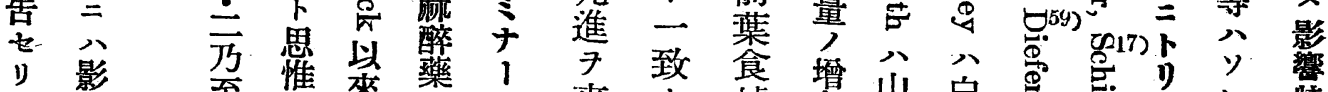

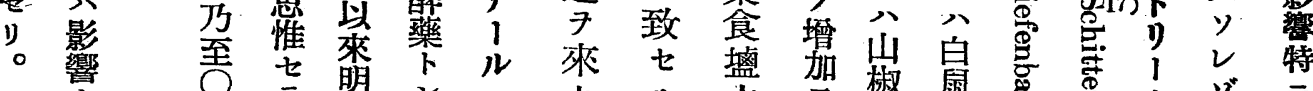

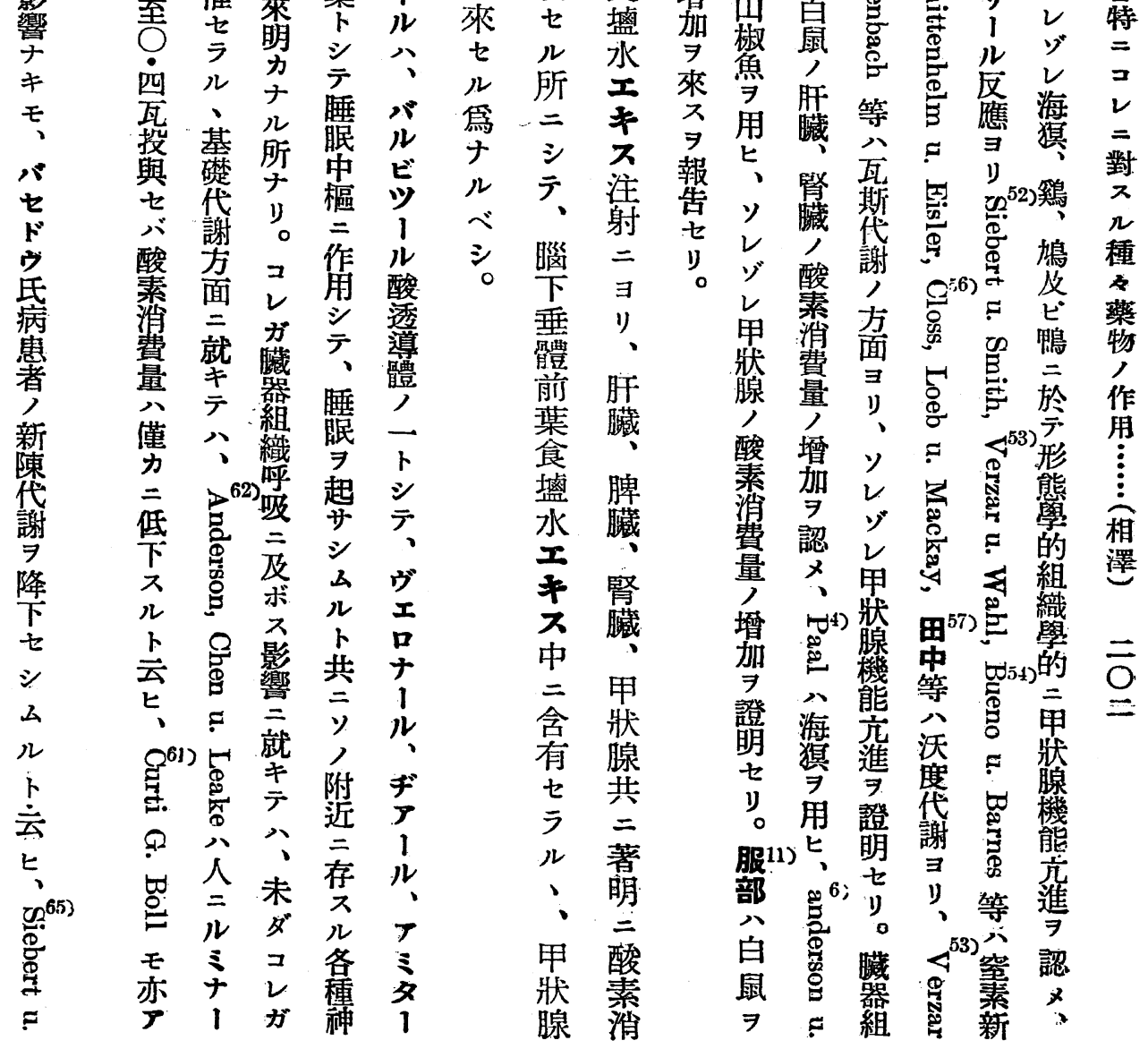




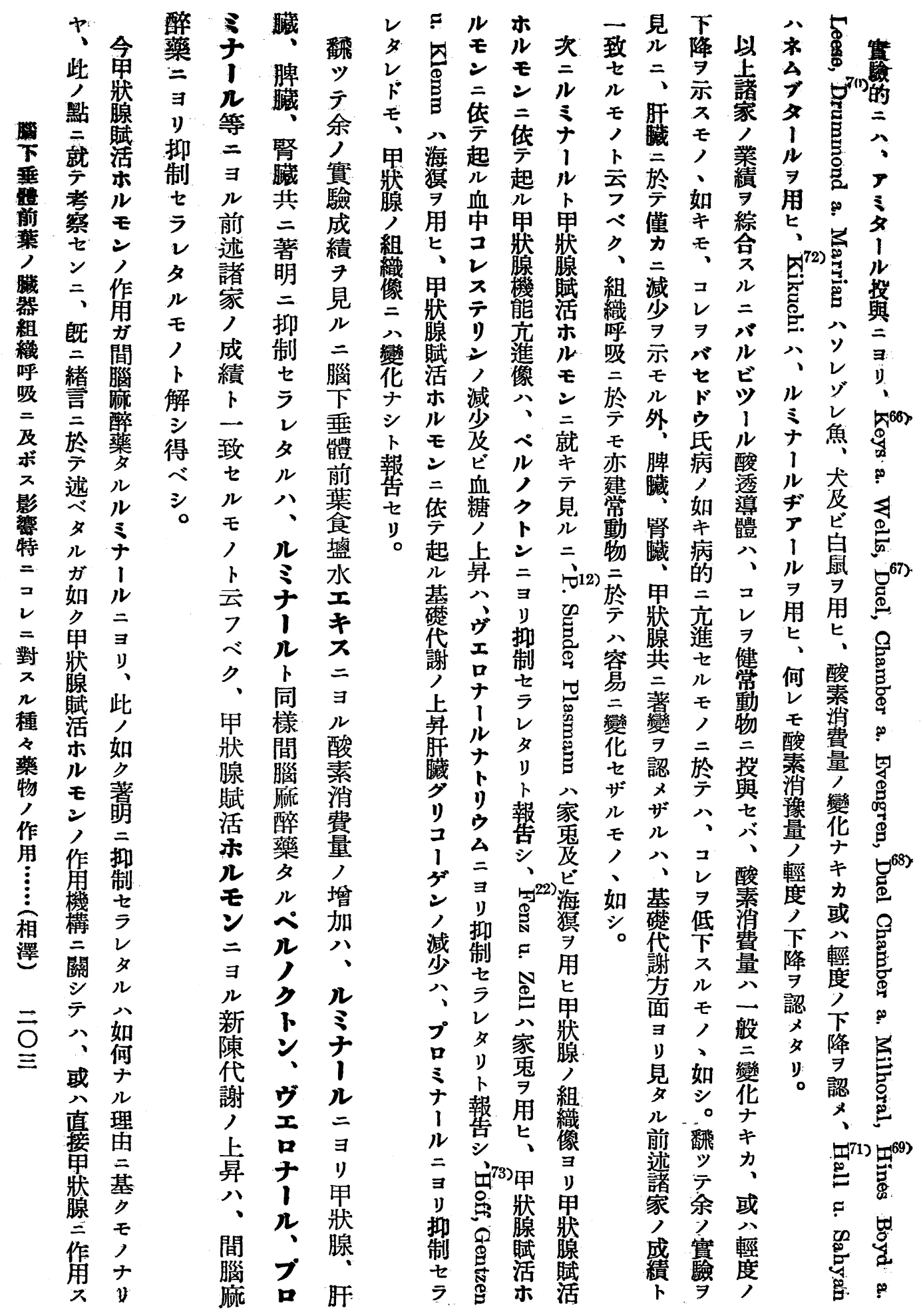




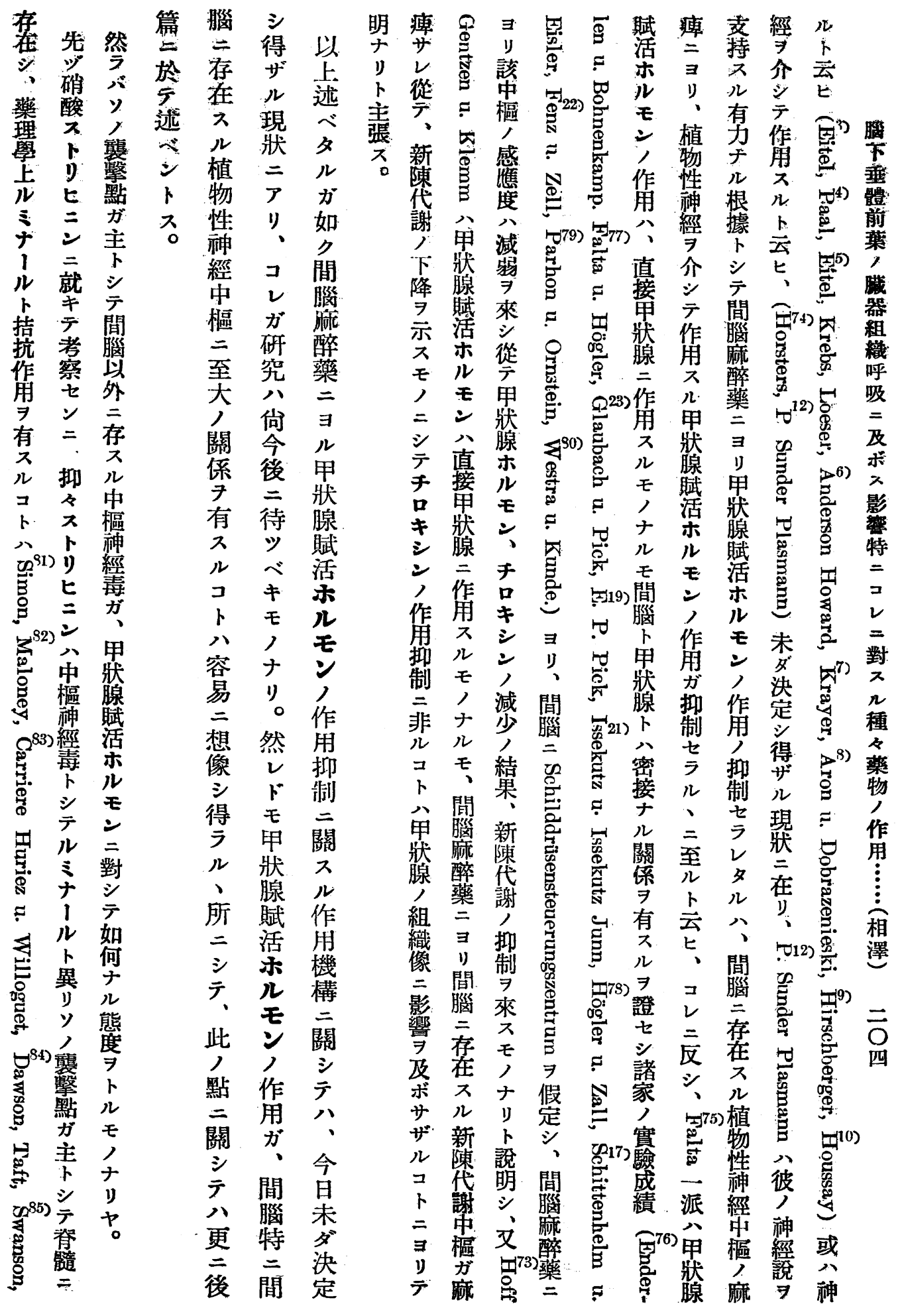




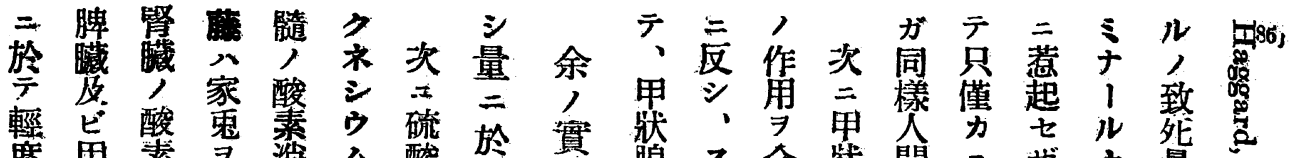

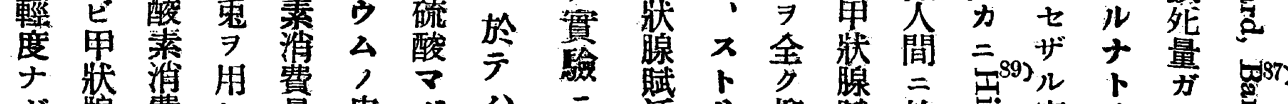

垂 $カ$ 㟲費

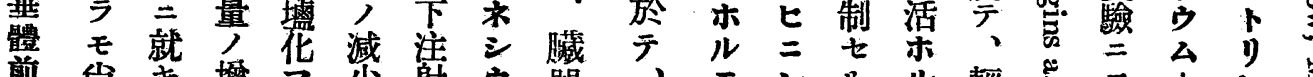

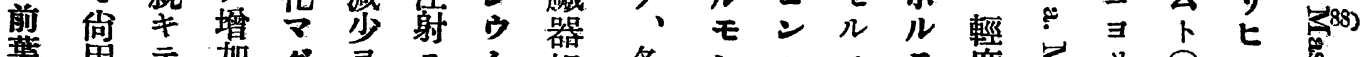

葉 牀

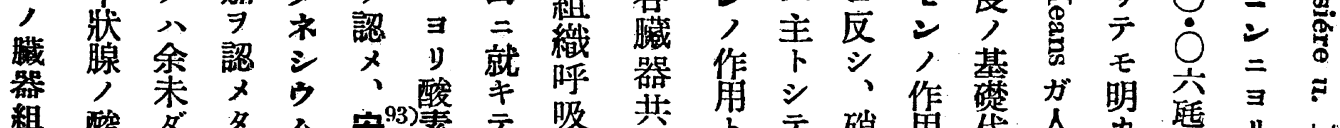

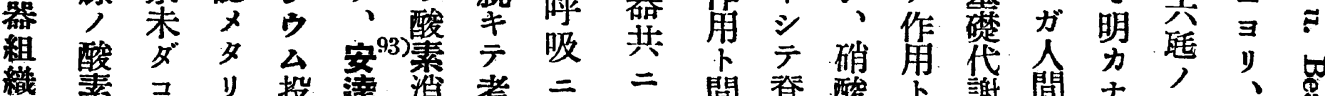

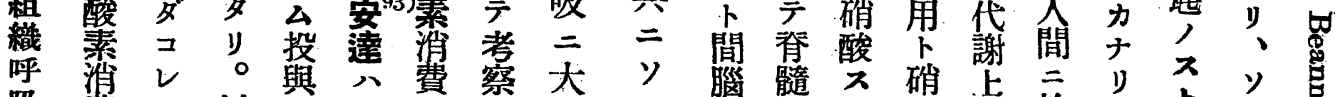

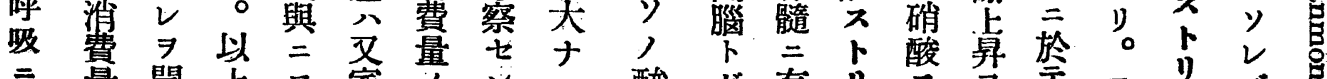

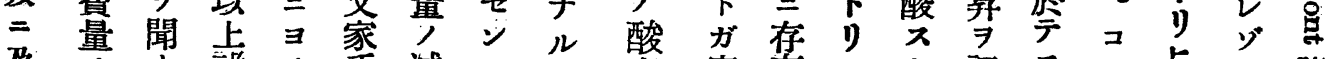

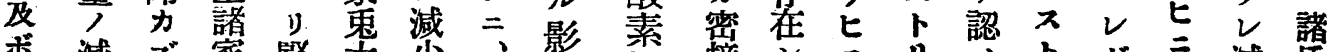

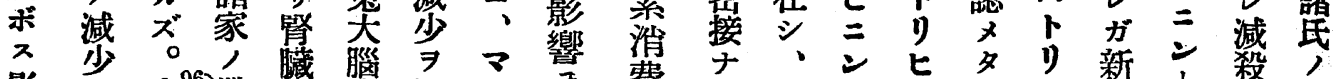

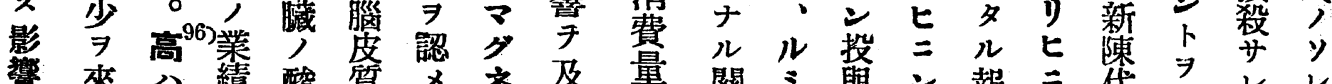

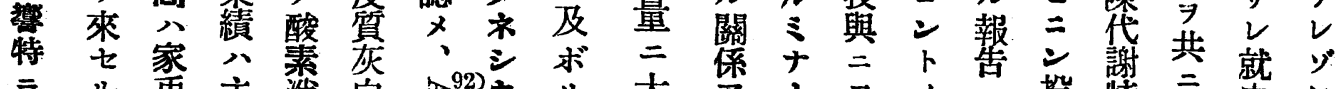

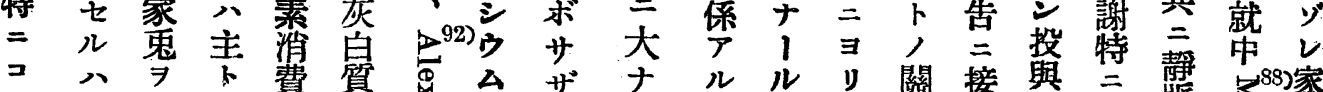

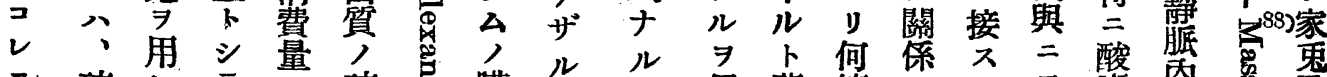

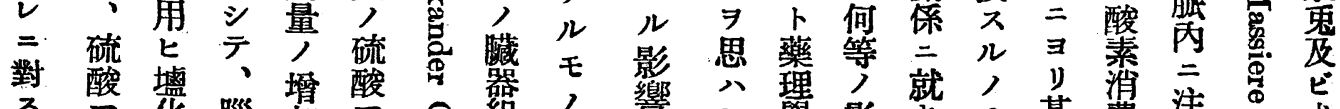

ス

種

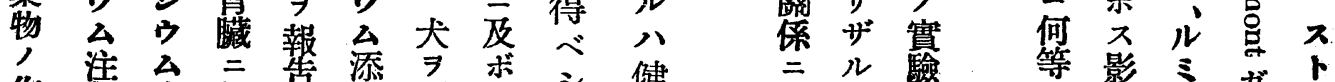

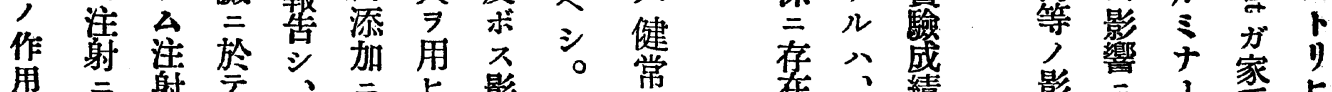

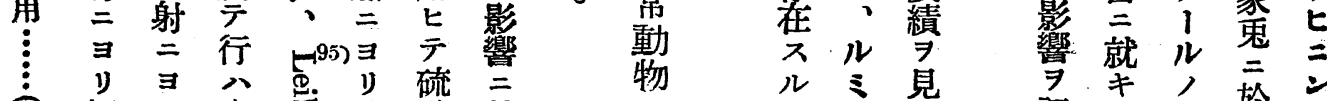

相輕 竖

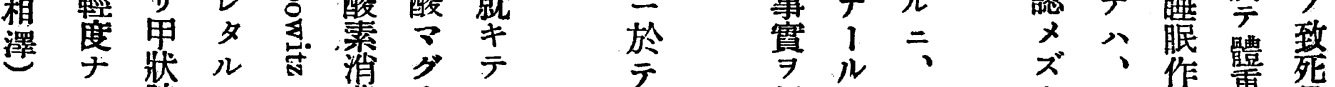

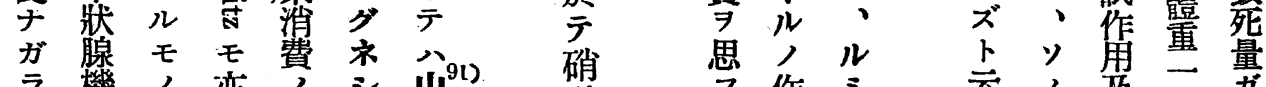

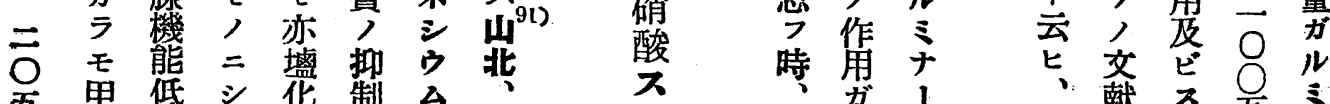

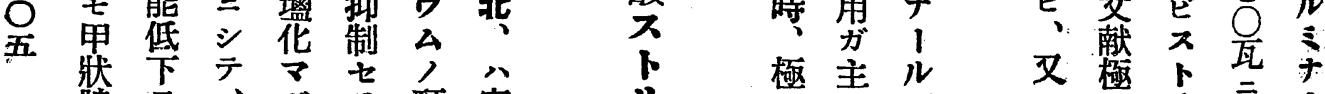

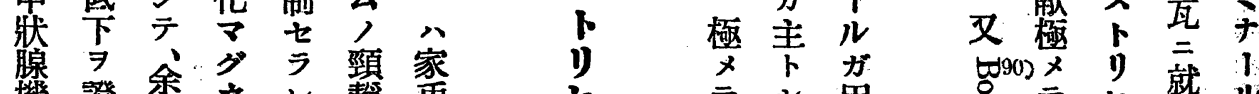

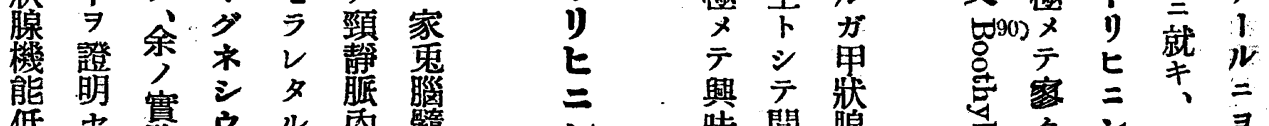

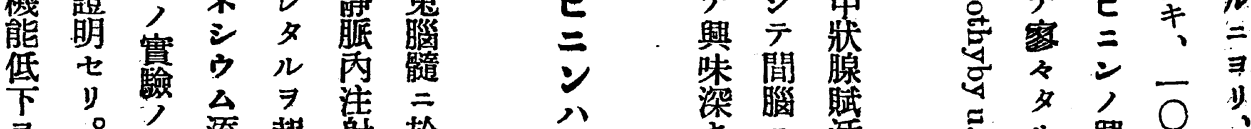

$\Rightarrow 00$ 台 7 添

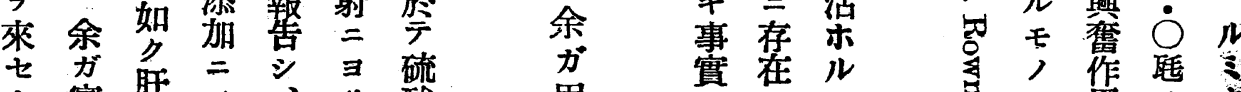

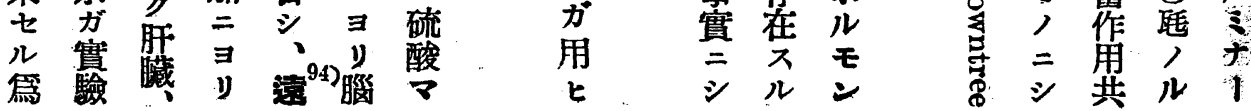




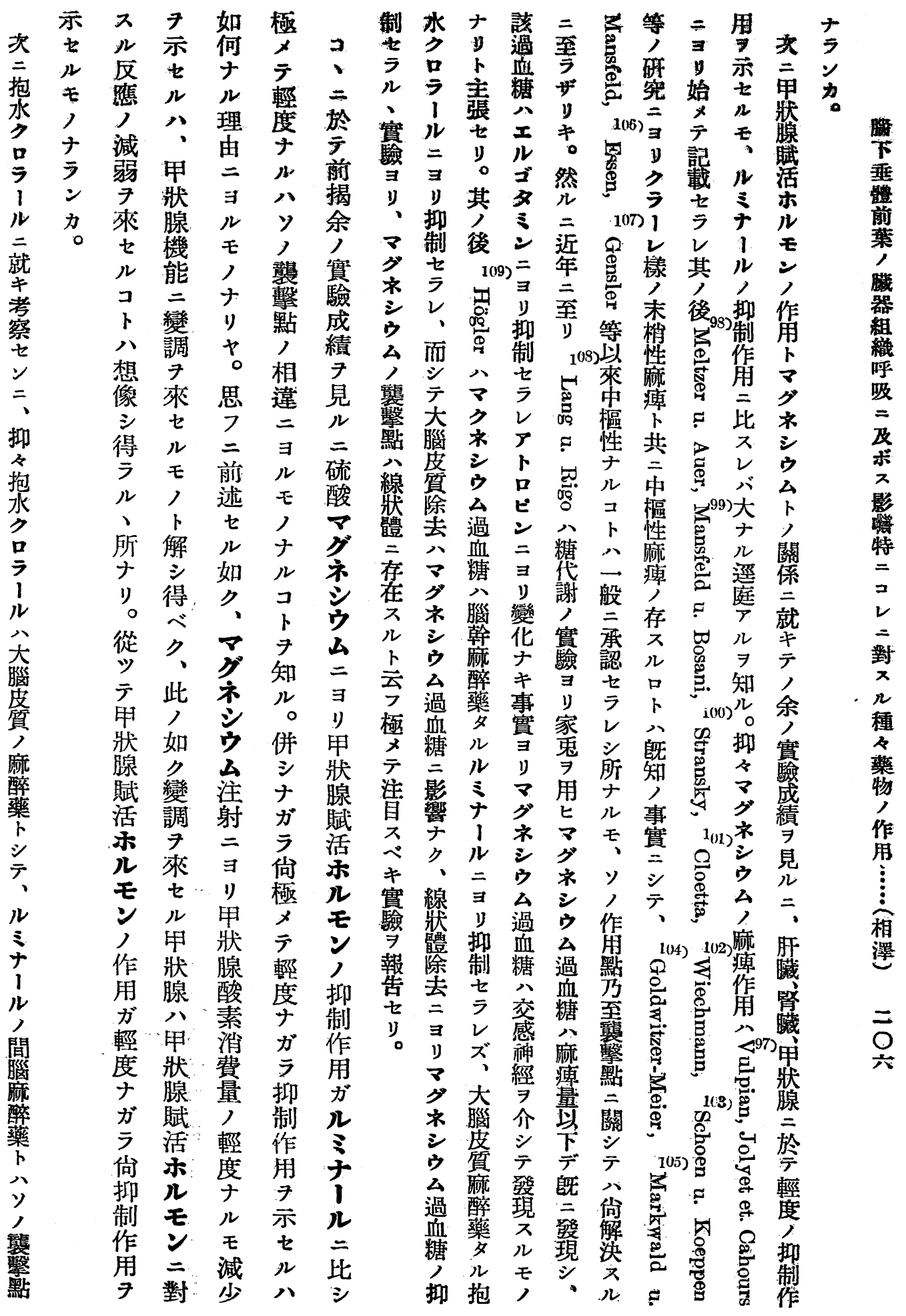




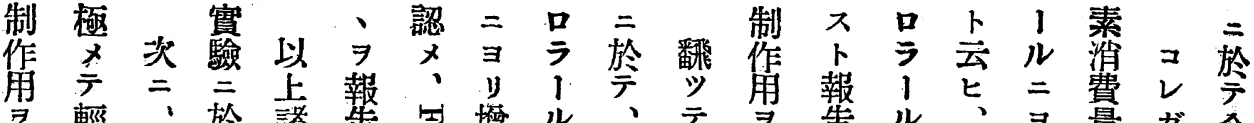

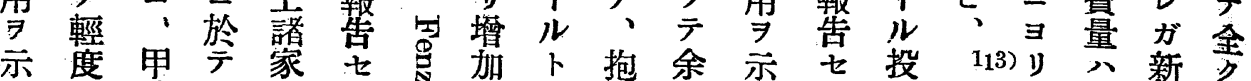

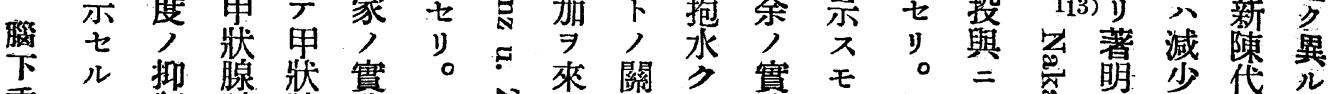

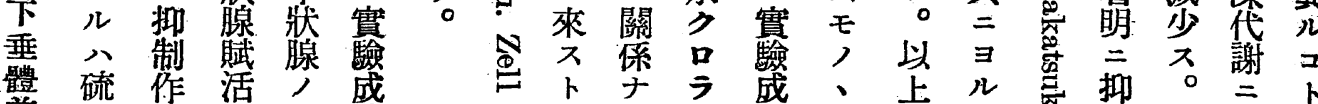

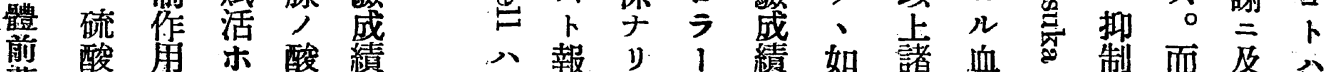

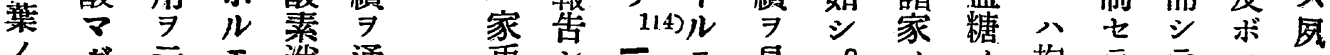

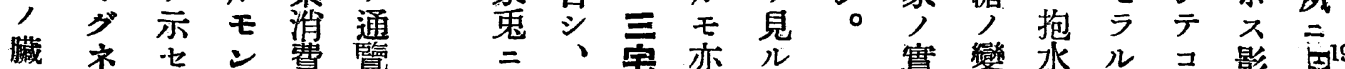
驗 戀 水 $ク$, 篦

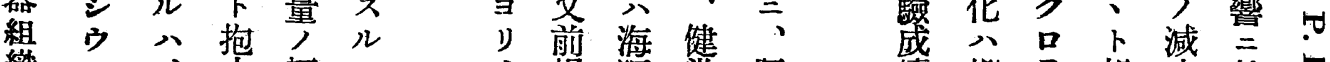
織么、水輕 二

呼 抱方度抱

吸同水口品水 二樣 ク カ ガク 及地品今品 辛抱 ラ ル

影響ル, 減ル

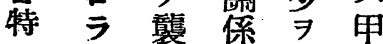

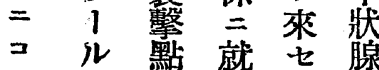

レ注 ガキル機

對射主穴

邓

几

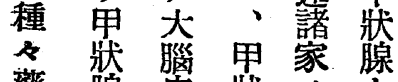

物腺筫腺成亦

午能二賦績モ

作 $=$ 存活等

用變在思,

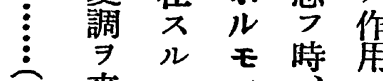

相 來 = 紧

澤 シ 寻作牀

二惩方角腺挂

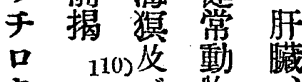

キ

投森 品於牀

與总 7 八

公用大於

ル界ヒ、ナ 羥

血腺 抱變 度

中虫水花 $=$

ス症品來制

$ヨ 1 \vee 5$

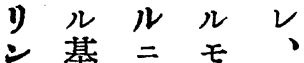

基濧と脾

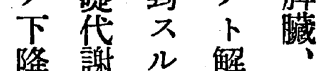

訝 解

血, 摧腎

糖 上 哲 得 贜

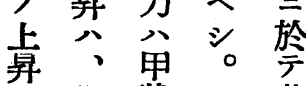

抱牀コ著

抱水晸、變

績 投

通量心缹度 キ

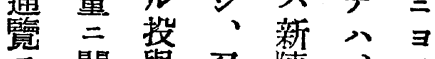

ス 關與又陳门リ

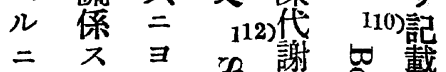

抱范寻吕謝若載

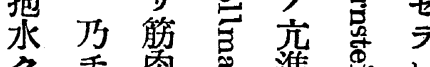

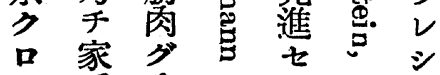

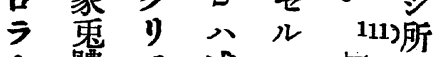

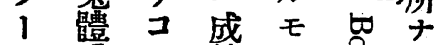

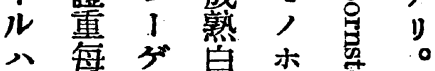

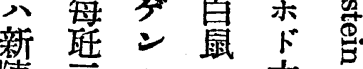

苻吾減於大

謝 琵少

對與血, 号六

テ 六糖 嵗界人

ソ血公長狀間

挆䌅点抱腺二

與變 ス水毒抱

量华几力症水

水 $\Rightarrow$ 剔 $=$ =

ヨ云引至品

ラ

七牀 揭低

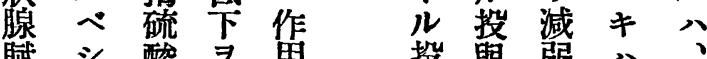

賦 シ 酸 $尹$ 角

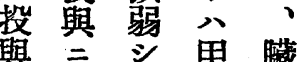

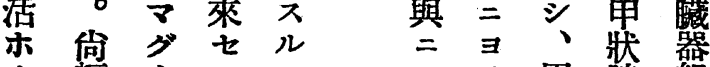

ル輕ネ゙モコリ腺組

モ度篇,

ンナウナ、

八劦㕕 ラ 如

抑正鼎機織

甲 ラ

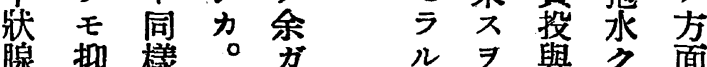

リ 一 ヒ 1 ルラ

或入、儿新 1

五 四78)投 陳

變 配 喝 與 帒 $尹$

华投與畐謝經

ク $=\mp \quad$ 上的

或 シ 仓

八血 $=$ 抱 與

輕糖八停氷セ

度八抱止方

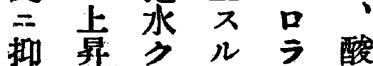


三狀 : 前 藮 余

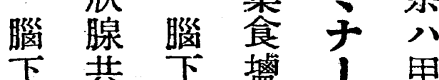

垂三垂水儿狀

體著體土ナ腺

前明 前 ₹ P 賦

葉二藮 $\boldsymbol{y}$ y 活

食抑食子方乘

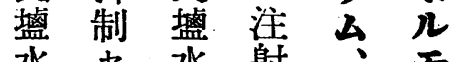

水七水 射

エ $匚$ シ 硝

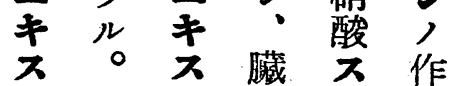

$=\quad$ 器占用

$\exists$ ヨ 組 $\boldsymbol{j}$ 分

ル $ル$ 織 $ヒ$ 中

酸酸呼三樞

素素 吸 $ン$ 神

渻渻

費費方 硫

量 量面 酸 如

增增 寻齐何

加 加檢采儿

、 八蔡离閶

硝少么 市

酸弪二、存

ス次抱 ス

1 1 , 水

リ $几$ 如 少

七学品,

小結 $三 ナ$

V y 論 1

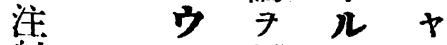

射 么 得 注 7

$=$ 注夕射 明

ヨ 射

1) $=0$ 行 $=$

奛寻然

藏蔵 ル

脾藏性

藏白、

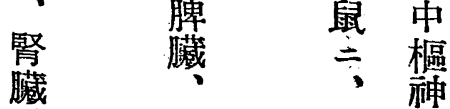

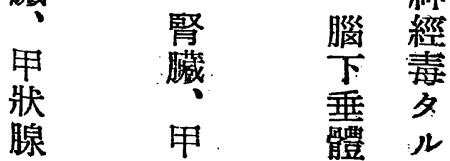

思以四三三 : 以

惟上抱硫硝 几上作

ス, 水酸酸 三余帮

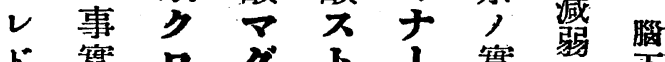

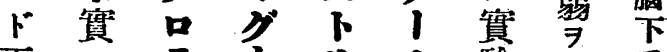

更二ラ未

二曰1シ ヒナ成七體

後りルウ三下績儿揱

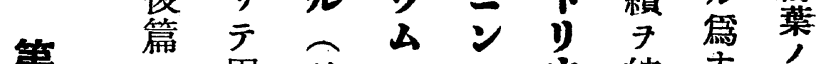

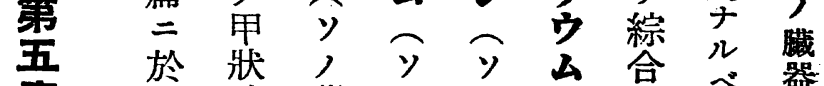

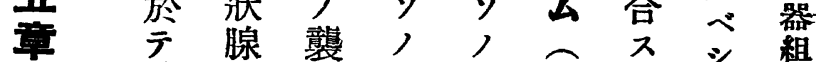

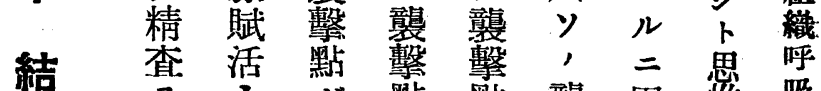

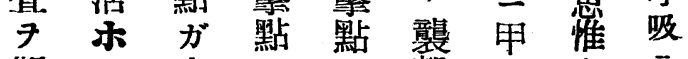

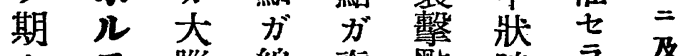

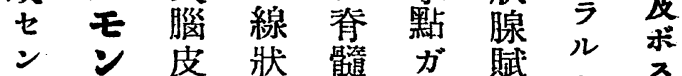

卜了質體皆間活文影

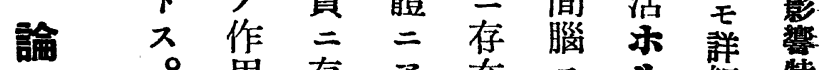

用存

八在り

間 ストル在方盆コ

腦 ル思しス, 後レ

特二惟二㤰篇

$==t \exists \smile$ 用奜搂

ソ $ヨ$ リ

ノリル、ヨ、論種

植輕二何 㳦要

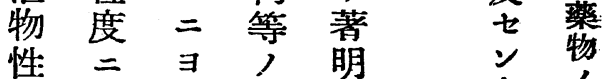

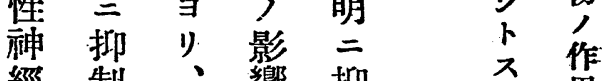

經 制響 抑分角

虫 七

樞 ラ度示

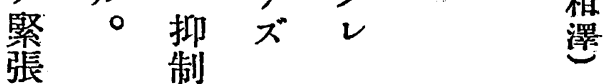

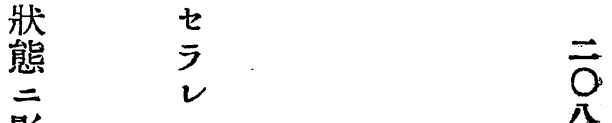

影

㗽

七

ラ

ル

S

)

t) 


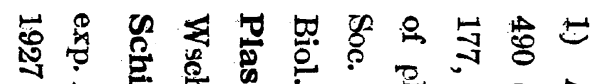

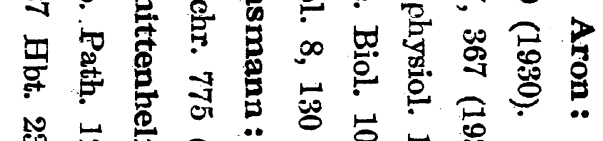

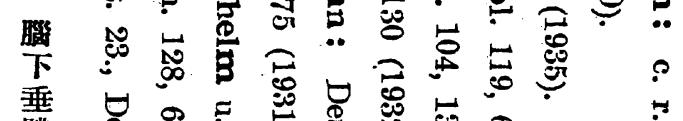

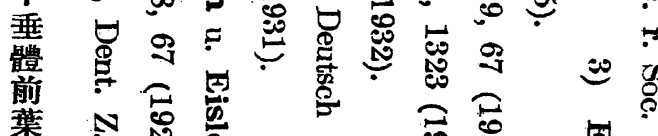

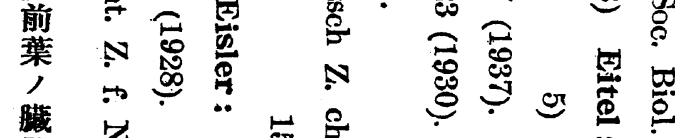

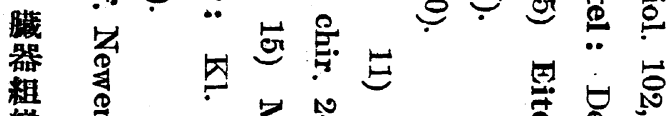

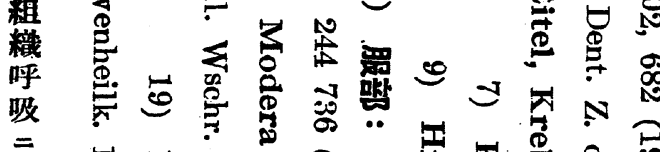

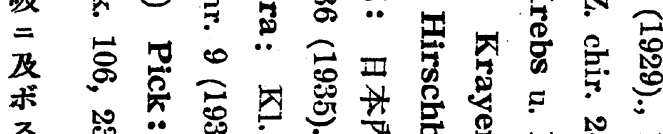

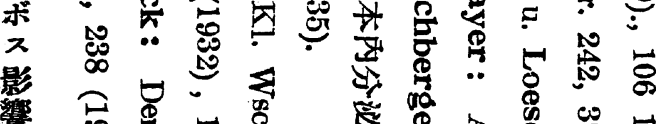

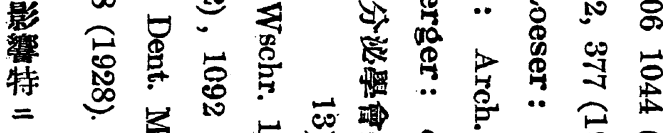

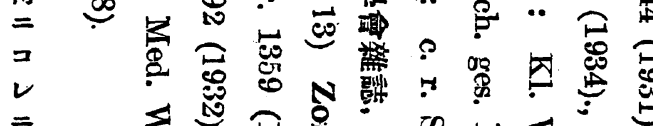

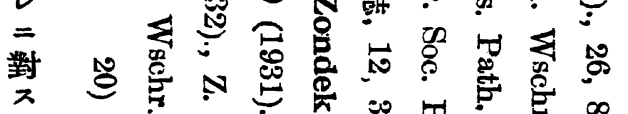

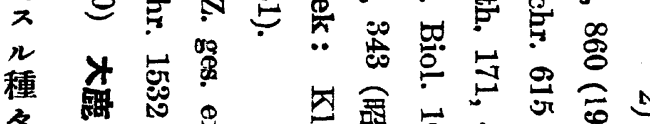

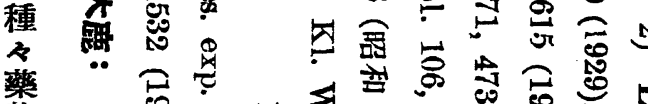

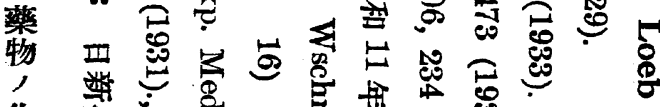

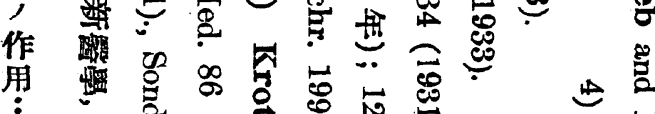

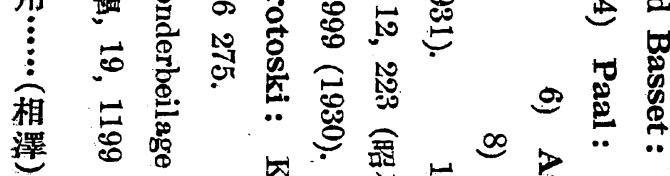

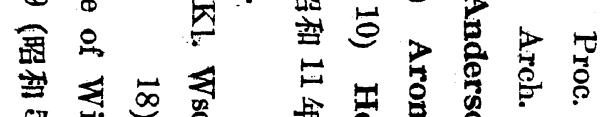

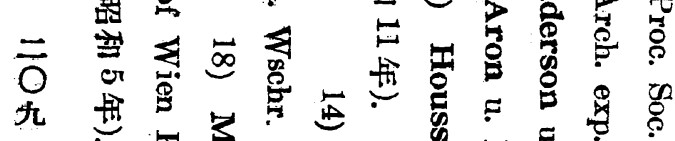

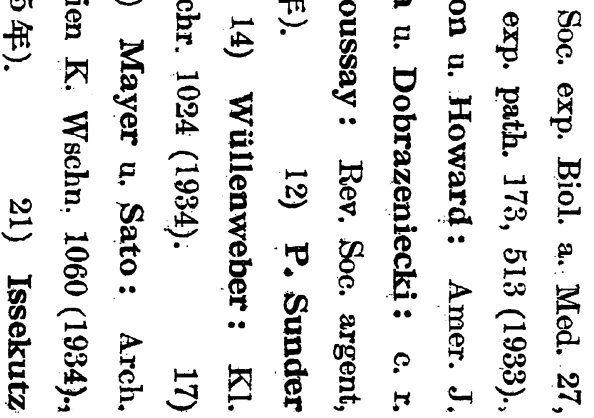

本诚

交 $=$

要

旨 終

第 御

十 愁

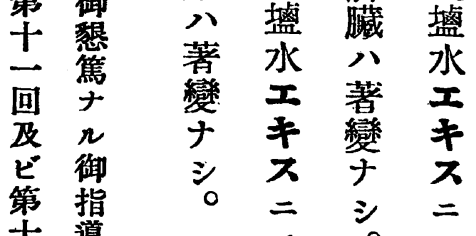

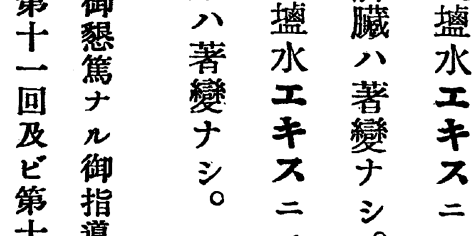

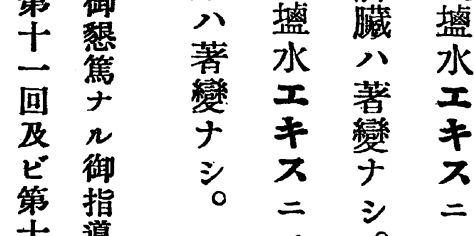

学導

早 翻

內

分 等

學 賜

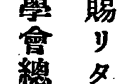

總會

席 恩

4 上師

於教

テ 授

發 並

表 三

》。宅

昞

謹

テ

謝

意

表

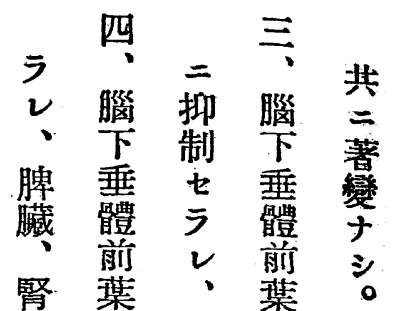

藏 食 脾 食

$\begin{array}{lll}\exists & 0 & \exists \\ \text { ル } & & \text { ル }\end{array}$

酸 酸

素素

渻渻

量量

增增

加加

拘 硫

水 酸

口 齐

ज

注㟔

射注

클

贜监

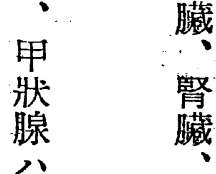

輕甲

度獎

抑 八

制䡒 


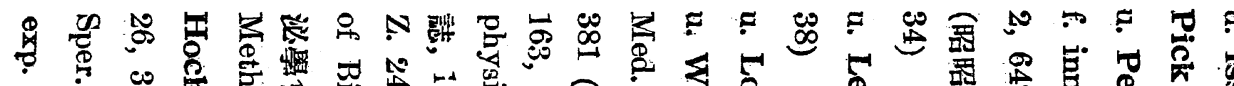

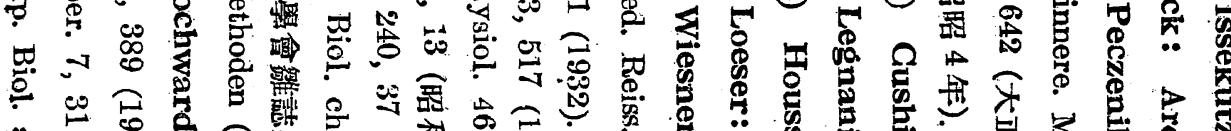

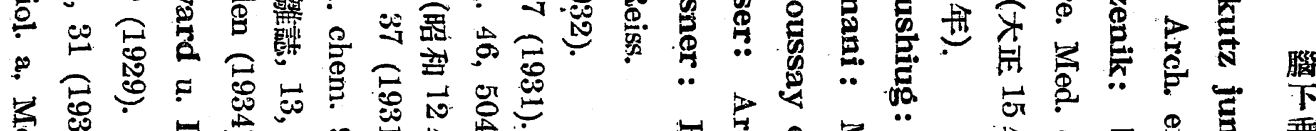

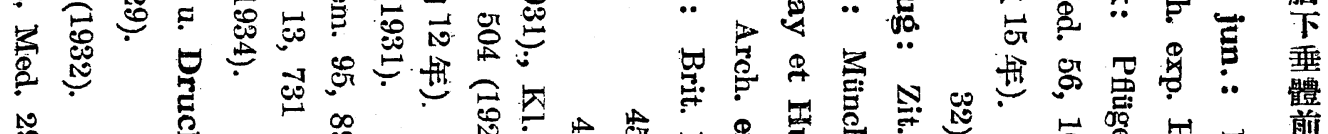

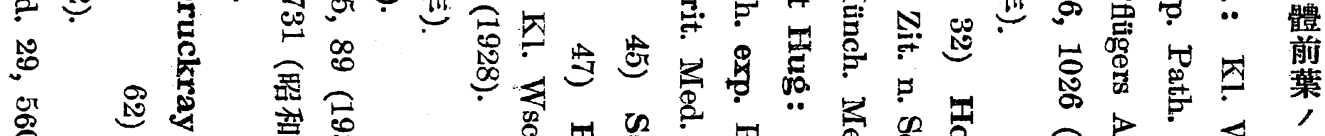

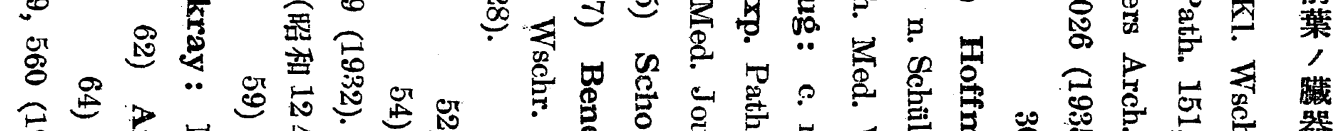

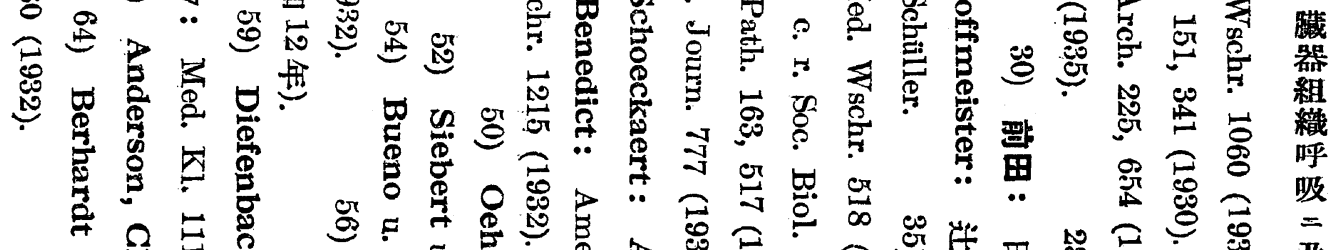

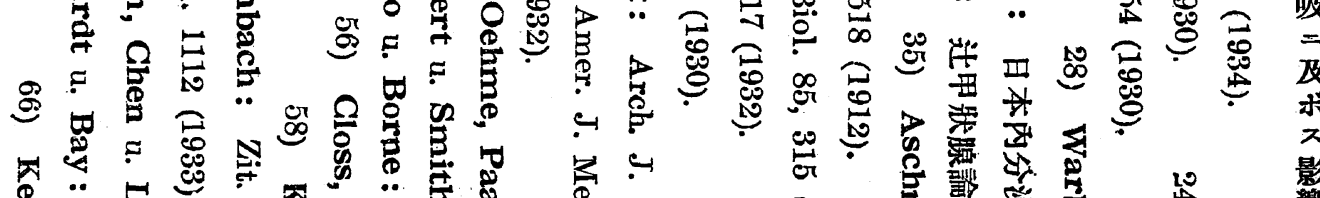

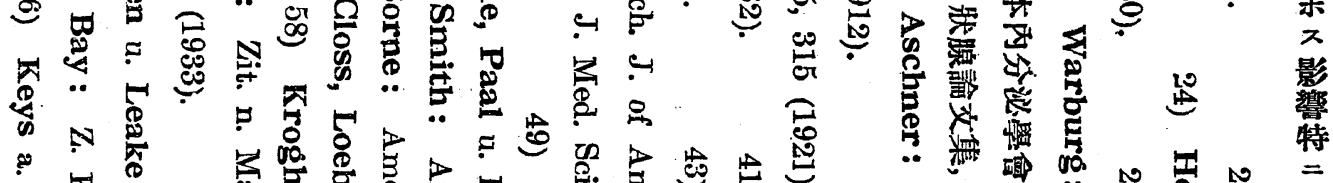

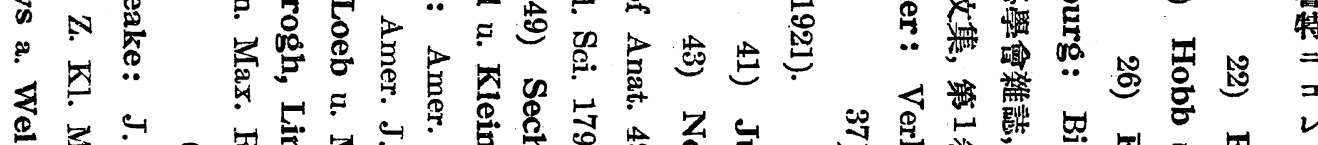

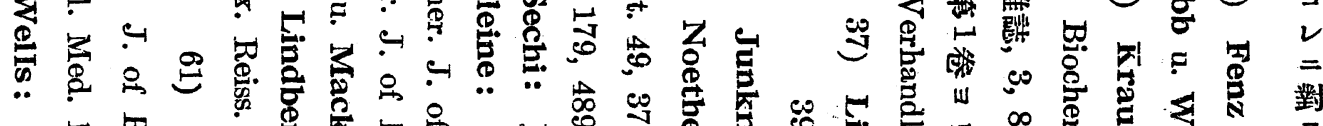

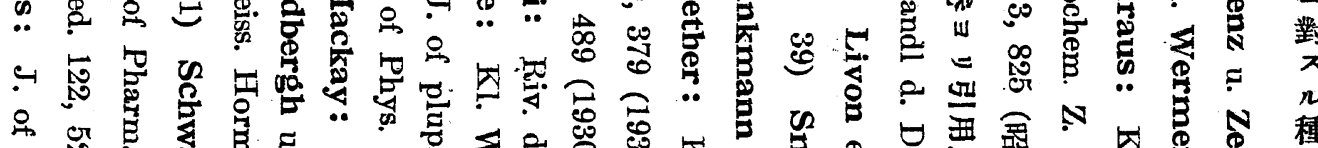

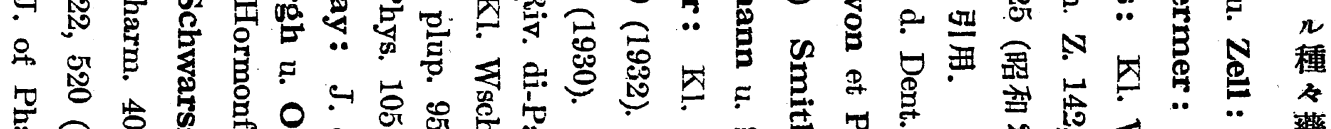

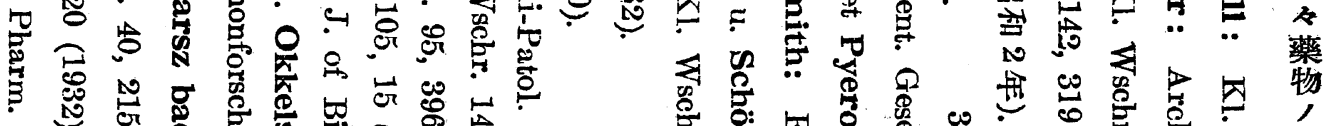

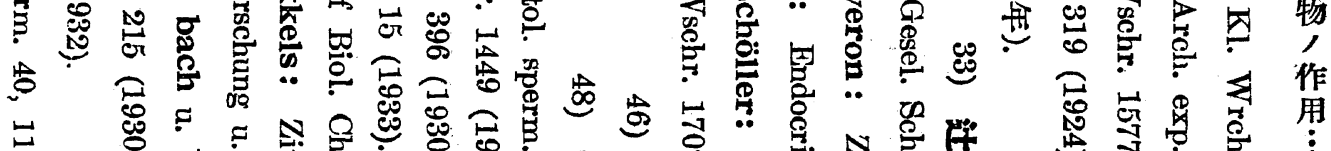

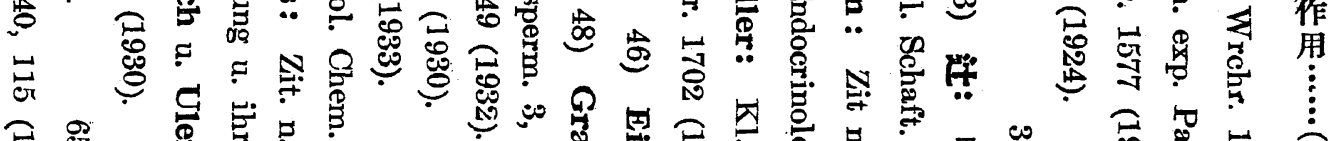

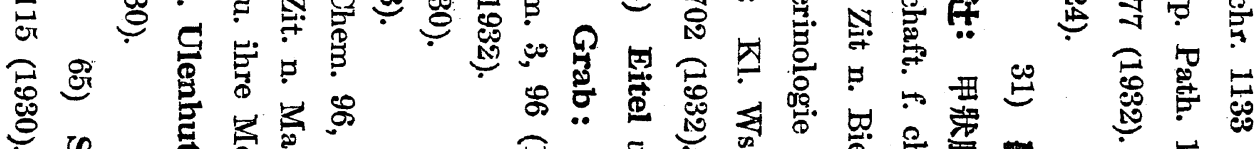

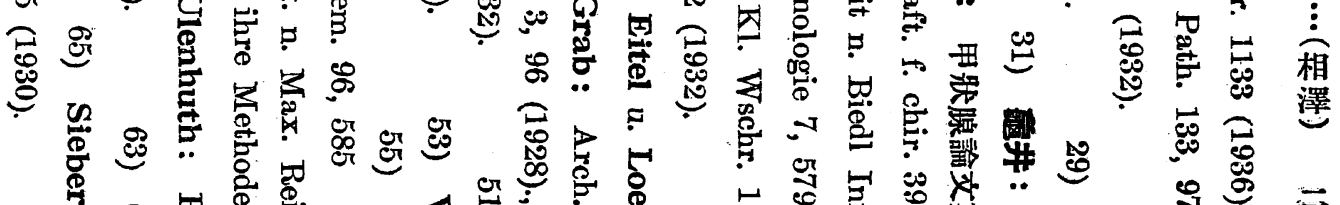

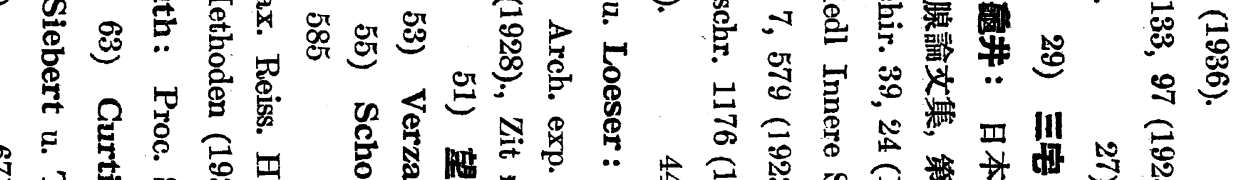

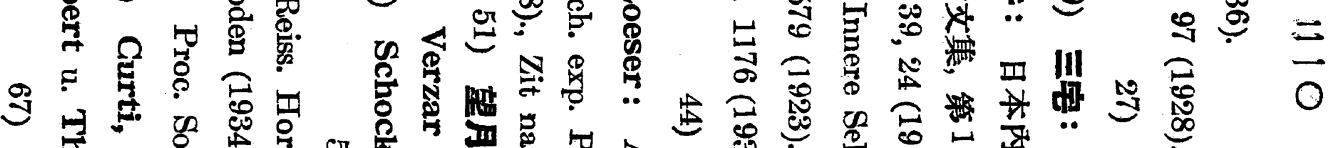

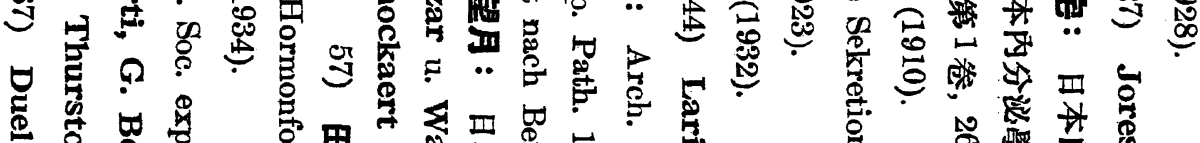

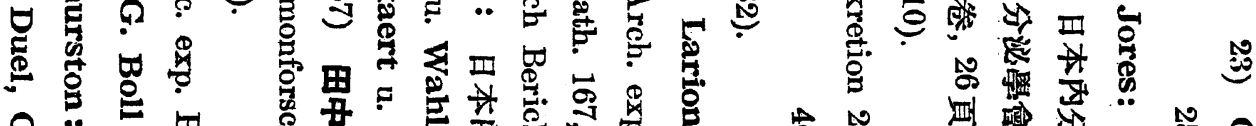

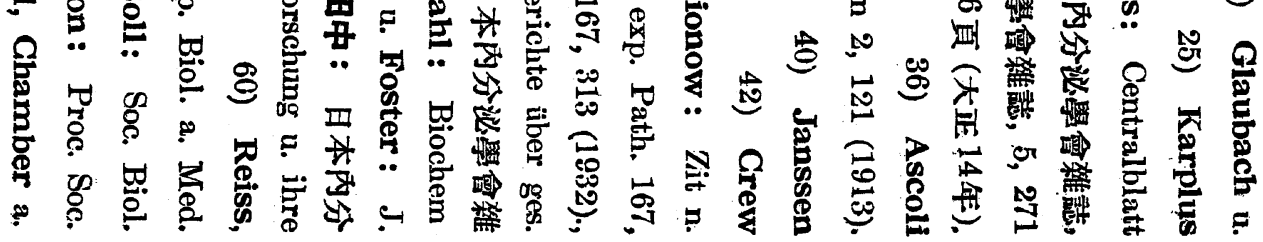




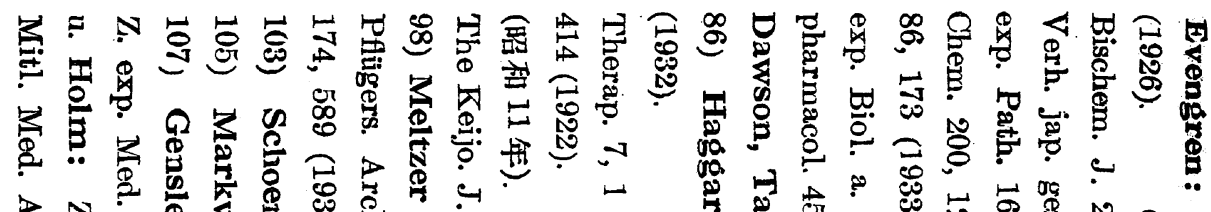

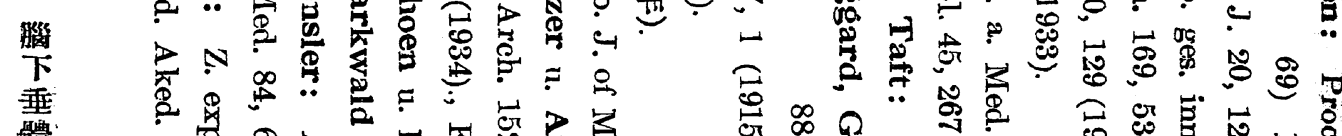

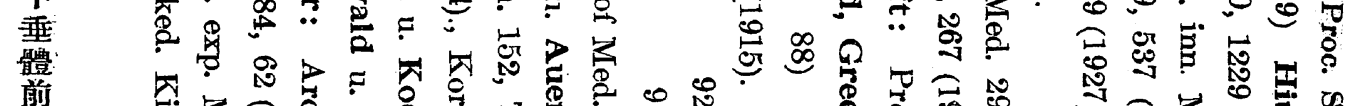

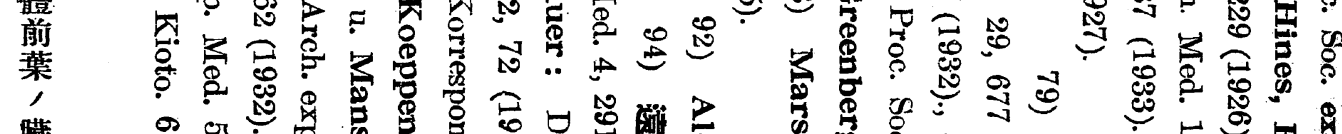

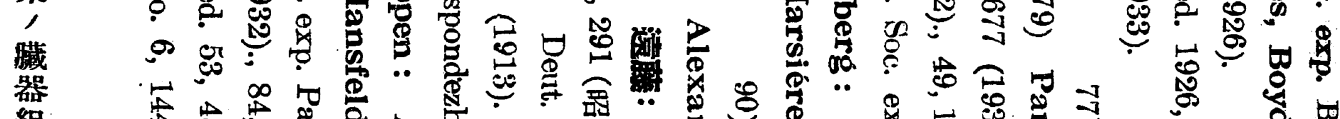

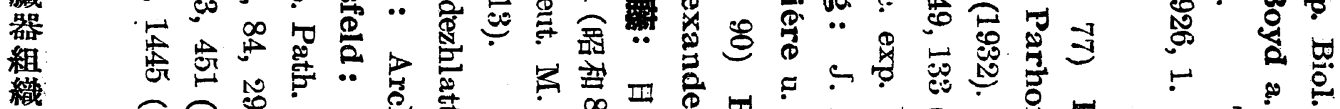

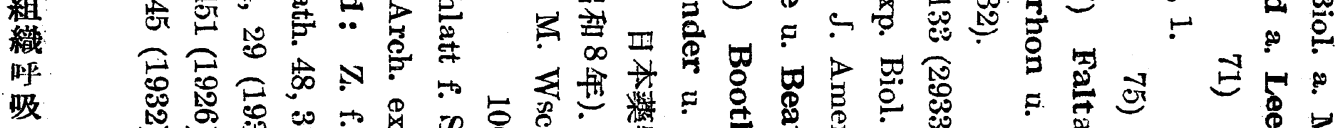

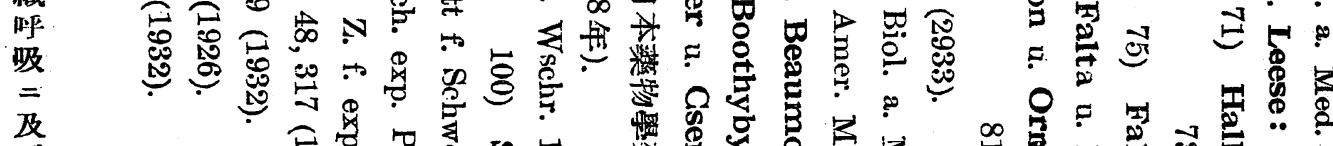

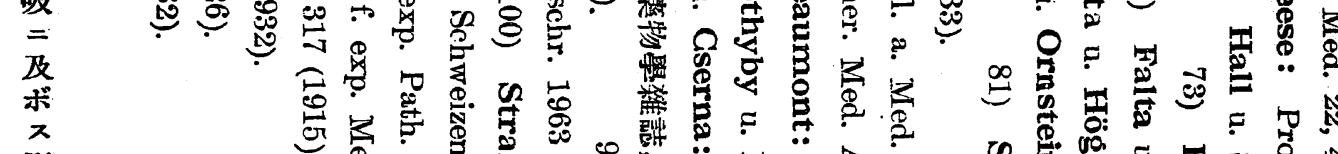

影

特

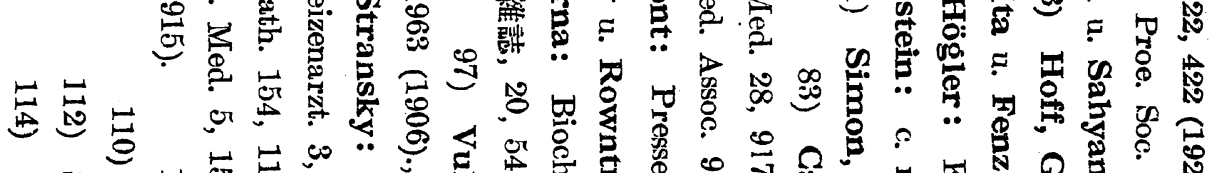

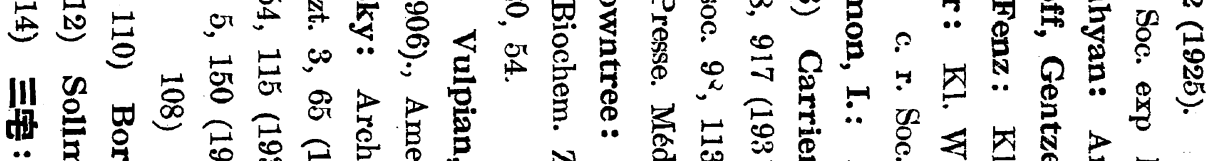

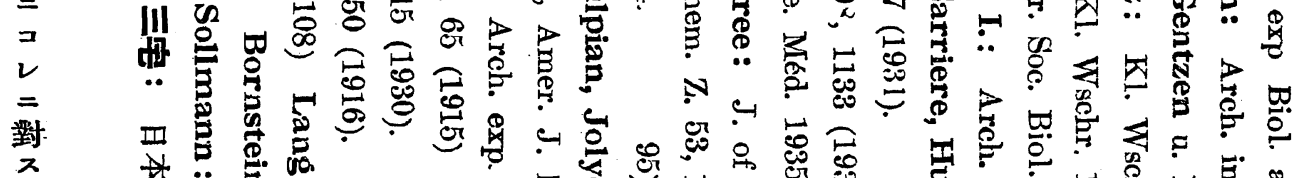

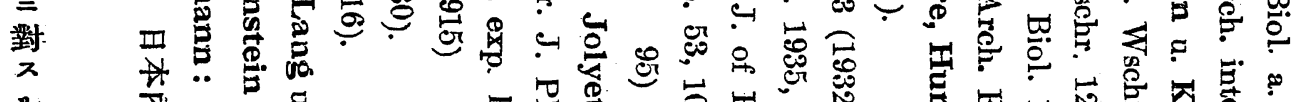

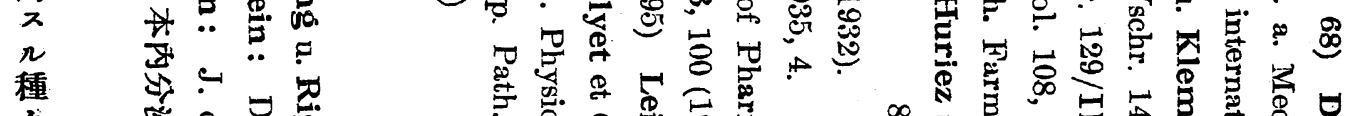

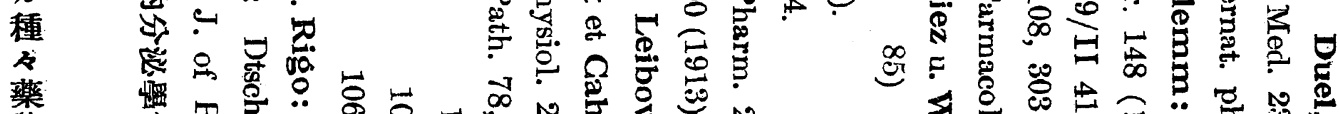

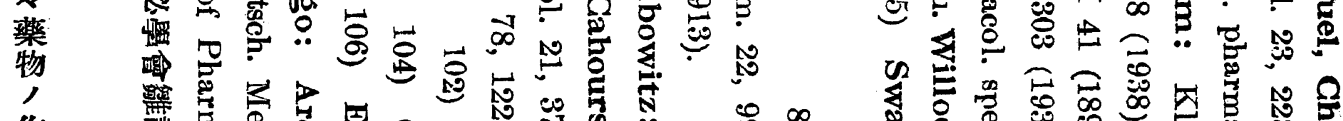

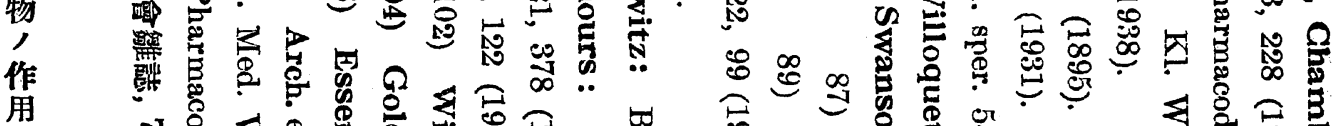

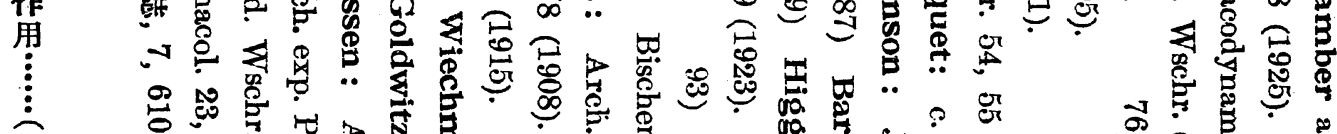

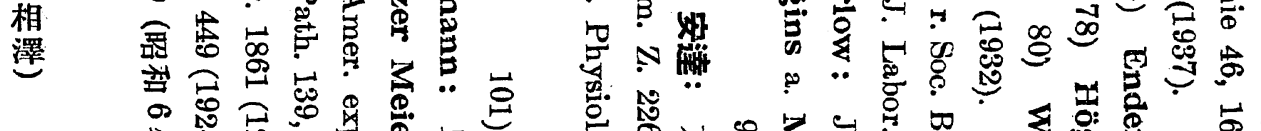

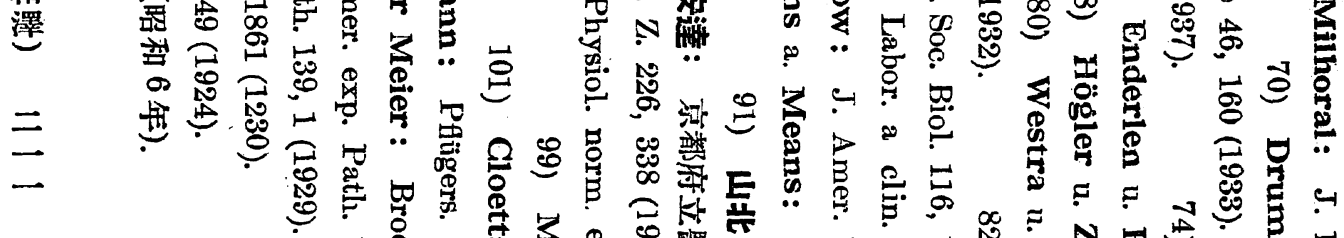

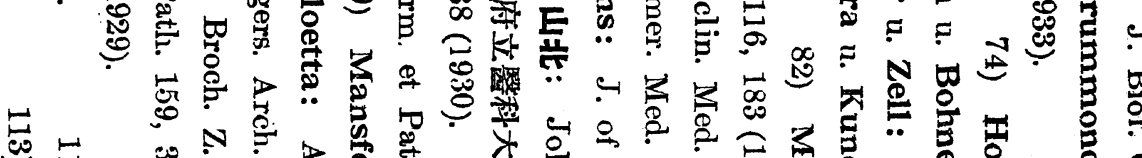

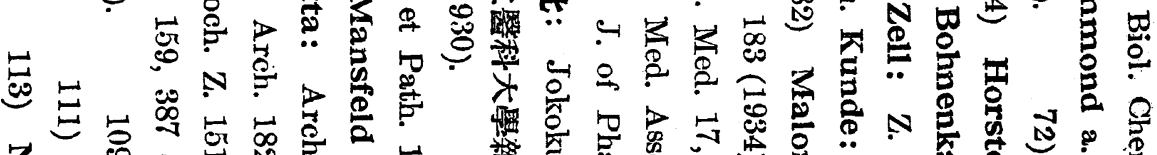

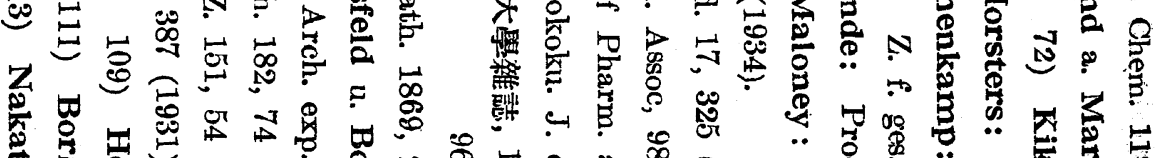

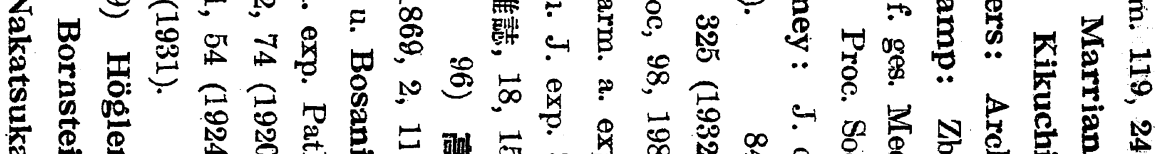

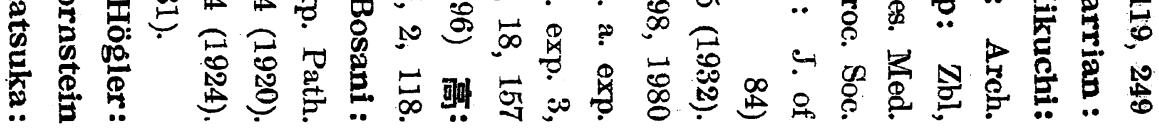


der Adrenalinempfindlichkeit hinsichtlich des Blutdrucks. Diese drei Substanzen wirken also nicht sympathicusreizend kurz nach der Injektion, sondern reizen erst nach fortgesetzter Injektion in grossen Mengen den Sympathicus allmählich.

3) Im Verlaufe der 5 Tage lang fortgesetzten Injektion des Epithelzellenextrakts und Kochsalzlösungsextrakts der Rinderschilddrüse nahm das Körpergewicht langsam ab, stieg der Blutdruck an und nahmen die Pulszahl und die Adrenalinempfindlichkeit zu. Kurz nach jeder Injektion, nämlich in der Zeit von der 5. bis 8. und von der 15. bis 18. Minute post injectionem, kam es auch zur Zunahme der Pulszahl, zu leichtem oder angedeutetem Anstieg des Blutdrucks und zur Steigerung der Adrenalinempfindlichkeit hinsichtlich des Blutdrucks. Danach wirken der Epithelzellenextrakt und der Kochsalzlösungsextrakt der Rinderschilddrüse, welch letzterer den wirksamen Faktor des ersteren in grossen Mengen enthält, sowohl kurz nach jeder Injektion als auch dauernd nach fortgesetzter Einverleibung stets sympathicusreizend.

(Autoreferat)

\section{Über den Einfluss des Hypophysenvorderlappens auf die Gewebsatmung, speziell über die Beeinflussbarkeit dieses Einflusses durch verschiedene Pharmaca. \\ I. Mitteilung.}

Über den Einfluss von Luminalnatrium, Strychninum nitricum, schwefelsaurem Magnesium und Chloralhydrat.

Von

Dr. Mitsuo Aisawa.

(Aus der I. Med. Klinik der Kaiserl. Universität zu Kyoto in Japan. Direktor: Prof. Dr. K. Tsuji).

Der Versuch wurde ausgeführt, um festzustellen, in welchem 
Zusammenhang die Wirkung des thyreotropen Hormons zu dem Zentralnervensystem steht. Zu diesem Zwecke wurden die in der Überschrift genannten Pharmaca zunächst gesunden männlichen Ratten 10 Tage lang subkutan einverleibt. Vom 6. bzw. 8. Tag nach Beginn der Pharmacainjektion an wurde jedem Versuchstier jeweils 3 bis 5 Tage lang $0.4 \mathrm{ccm}$ Kochsalzlösungsextrakt des Hypophysenvorderlappens (per $100.0 \mathrm{~g}$ Körpergewicht $0.02 \mathrm{~g}$ getrockneten Vorderlappens entsprechend) eingespritzt. Die tägliche Injektionsdosis der verschiedenen Pharmaca war pro $100.0 \mathrm{~g}$ Körpergewicht wie folgt :

Luminalnatrium $0.01 \mathrm{~g}$, Strychninum nitricum $0.02 \mathrm{mg}$, Magnesium sulfuricum $0.05 \mathrm{~g}$ und Chloralhydrat $0.015 \mathrm{~g}$. Die Messung der Gewebsatmung erfolgte nach der Warburgschen Methode. Es wurden Leber, Milz, Niere und Schilddrüse untersucht. Verglichen wurde mit den bei einfacher Einverleibung der Vorderlappensubstanz festgestellten Ergebnissen.

Die Arbeitsergebnisse waren etwa wie folgt:

1) Die bei der Einverleibung des $\mathrm{NaCl}$-lösungsextrakts des Vorderlappens zu beobachtende Steigerung des Sauerstoffverbrauches der Leber, der Milz, der Niere und der Schilddrüse wird durch Vorbehandlung mit Luminalnatrium deutlich herabgesetzt.

2) Die bei der Einverleibung des NaCl-lösungsextrakts des Vorderlappens vorkommende Steigerung des $\mathrm{O}_{2}$-Verbrauches verschiedener Organe wird durch Vorbehandlung mit Strychninum nitricum nicht wesentlich beeinflusst.

3) Die bei der Einverleibung des NaCl-lösungsextraktes des Vorderlappens zu beobachtende Steigerung des $\mathrm{O}_{2}$-Verbrauches wird durch Vorbehandlung mit Magnesium sulfuricum in der Leber, der Niere und der Schilddrüse leicht herabgesetzt, in der Milz dagegen nicht wesentlich beeinflusst.

4) Die bei der Einverleibung des NaCl-lösungsextrakts des Vorderlappens zu beobachtende Steigerung des $\mathrm{O}_{2}-$ Verbrauches wird durch Vorbehandlung mit Chloralhydrat in der Leber und der Schilddrüse leicht herabgesetzt, in der Milz und der Niere dagegen nicht wesentlich beeinflusst.

(Autoreferat) 